MARGARET HWANG SMITH

Pomona College

G A R Y S M I T H

Pomona College

\title{
Bubble, Bubble, Where's the Housing Bubble?
}

HOUSING PRICES HAVE risen by about 50 percent in the past five years, and more than 100 percent in some hot markets. Many knowledgeable observers believe that the United States is in the midst of a speculative bubble in residential real estate prices that rivals the dot-com bubble of the 1990s and that will have a similarly unhappy conclusion.

In December 2004 UCLA Anderson Forecast's Economic Outlook described the California housing market as a bubble, repeating their warnings made in previous years. Robert Shiller has issued similar alarms for several years and, in June 2005, warned that, "The [housing] market is in the throes of a bubble of unprecedented proportions that probably will end ugly." Shiller suggests that real housing prices might fall by 50 percent over the next decade. In August 2005 Paul Krugman argued that there was definitely a housing bubble on the coasts and that, indeed, the air had already begun leaking out. ${ }^{2}$

Evidence of a housing bubble has been suggestive but indirect, in that it does not address the key question of whether housing prices are justified by the value of the services provided by a home. We first show how to estimate the fundamental value of a home from rent data. We then use this procedure to estimate the fundamental value of homes in ten urban housing

This research was supported by the John Randolph Haynes and Dora Haynes Foundation. We are grateful to Alan Blinder, Brian Chew, Jay Daigle, Daniel Harding, Edmund Helmer, Jesse Licht, Steve Marks, Christopher Mayer, Thomas Renkert, John Romeo, Samuel Ross, and Robert Shiller for their assistance and many helpful comments.

1. Robert Shiller, "The Bubble's New Home," Barron's, June 20, 2005.

2. Paul R. Krugman, "That Hissing Sound," The New York Times, August 8, 2005. 
markets using a unique set of rent and sale price data for matched singlefamily homes. Our evidence indicates that, even though prices have risen rapidly and some buyers have unrealistic expectations of continuing price increases, the bubble is not, in fact, a bubble in most of these areas: under a variety of plausible assumptions about fundamentals, buying a home at current market prices still appears to be an attractive long-term investment.

Our results also demonstrate that models that gauge a housing bubble by comparing movements in housing price indexes with movements in other indexes or with the values predicted by regression models are flawed, because they assume that market prices fluctuate randomly around fundamental values. Those models must assume that prices were close to fundamentals in the past in order to conclude that the 2001-05 run-up pushed prices above fundamentals. But maybe prices were below fundamentals in the past and the 2001-05 run-up pushed prices closer to fundamentals.

\section{Defining a Bubble}

Charles Kindleberger defined a bubble this way:

a sharp rise in price of an asset or a range of assets in a continuous process, with the initial rise generating expectations of further rises and attracting new buyers - generally speculators interested in profits from trading in the asset rather than its use or earning capacity. The rise is usually followed by a reversal of expectations and a sharp decline in price often resulting in financial crisis. ${ }^{3}$

Researchers often focus on a single specific aspect of this general concept: rapidly rising prices ${ }^{4}$ unrealistic expectations of future price increases,${ }^{5}$ the departure of prices from fundamental value, ${ }^{6}$ or a large drop in prices after the bubble pops. ${ }^{7}$

Shiller and Karl Case write that, "A tendency to view housing as an investment is a defining characteristic of a housing bubble." trary, we believe that housing is an investment and that the correct way to gauge a bubble is to compare actual home prices with the value of homes

3. Kindleberger (1987, p. 281).

4. Baker (2002).

5. Case and Shiller (2003).

6. Garber (2000).

7. Siegel (2003, p. 3$)$.

8. Case and Shiller (2003, p. 321). 
as an investment calculated from fundamentals (and that one of the main sources of mispricing in the housing market is that almost none of the participants estimate the fundamental value of their home).

We define a bubble as a situation in which the market prices of certain assets (such as stocks or real estate) rise far above the present value of the anticipated cash flow from the asset (what Kindleberger called the asset's use or earning capacity). This definition suggests many of the features noted above: prices rising rapidly, a speculative focus on future price increases rather than the asset's cash flow, and an eventual drop in prices. However, these features are only suggestive. Market prices can rise rapidly if fundamental values are increasing rapidly or if prices are far below fundamental values. Market prices can drop (for example, in a financial crisis) even when there has been no bubble. What truly defines a bubble is that market prices are not justified by the asset's anticipated cash flow.

\section{Is the Housing Market Efficient?}

True believers in efficient markets might deny that there can ever be a bubble. The market price is always the correct price and is therefore justified by the expectations market participants hold. Even Jeremy Siegel, who believes there can be bubbles, writes that "We know that the price of any asset is the present value of all future expected cash flows." Contrast this with the opening sentence of John Burr Williams' classic treatise, The Theory of Investment Value: "Separate and distinct things not to be confused, as every thoughtful investor knows, are real worth and market price." ${ }^{10}$ In the stock market these two arguments can perhaps be reconciled by a consideration of whether the anticipated cash flows that investors use to calculate present values are reasonable. One way in which the residential real estate market is fundamentally different is that homebuyers generally do not calculate present values.

Case and Shiller report survey evidence of homeowners' naivety about the real estate market. ${ }^{11}$ The residential real estate market is populated by amateurs making infrequent transactions on the basis of limited information and with little or no experience in gauging the fundamental value of the properties they are buying and selling. It is highly unlikely

9. Siegel (2003, p. 3, emphasis in original).

10. Williams (1938, p. 3).

11. Case and Shiller (2003). 
that residential real estate prices are always equal to the present value of the expected cash flow if market participants almost never attempt to estimate the present value of the expected cash flow.

Instead, the nearly universal yardstick in residential real estate is "comps," the recent sale prices of nearby homes with similar characteristics. Comps tell us how much others have paid for homes recently, but not whether these prices are justified by the cash flow. Is a Britannia the British Bear Beanie Baby worth $\$ 500$ because a Princess Beanie Baby sold for $\$ 500$ ? Is this house worth $\$ 1$ million because a similar house sold for $\$ 1$ million? The widespread use of comps by buyers, sellers, real estate agents, and appraisers is the very mechanism by which market prices can wander far from fundamental values. If no one is estimating fundamental value, why should anyone assume that market prices will equal fundamental values?

In the stock market, professional investors can, in theory, arbitrage and exploit the mistakes made by noise traders. In the housing market, however, professionals cannot sell homes short and cannot obtain the tax advantages available for owner-occupied housing by physically occupying multiple homes. It is also expensive to manage and monitor rental properties, especially from afar. If a myopic focus on comps causes housing prices to depart from fundamentals, there is no immediate self-correcting mechanism.

In such an inefficient market, prices can be above or below fundamental value. Housing bubble enthusiasts implicitly assume that market prices were, on average, equal to fundamental values in the past in order to conclude that recent increases have pushed prices above fundamental values. Perhaps, instead, housing prices were too low in the past and recent price increases have brought market prices more in line with fundamentals.

\section{Bubblemetrics}

Researchers have used a variety of proxies to gauge whether there is a bubble in the real estate market. One pervasive problem is the reliance on aggregate measures of housing prices that are notoriously imperfect, for several reasons: homes are heterogeneous in their characteristics and location; it is difficult to measure the depreciation of existing properties or the value added by remodeling; and it is difficult to measure changes in the quality of home construction over time. Jonathan McCarthy and Richard Peach show that, between 1977 and 2003, four popular home price indexes 
differed markedly in their estimates of price appreciation, ranging from 199 percent (constant-quality new homes) to 337 percent (median sale price for existing homes). ${ }^{12}$

Even if the price indexes were perfect, their application is questionable. For example, Case and Shiller look at the ratio of housing prices to household income, the idea being that housing prices are a bubble waiting to pop if the median buyer is priced out of the market. ${ }^{13}$ But the affordability of a home does not tell us whether the price is above or below its intrinsic value. Berkshire Hathaway stock currently sells for nearly $\$ 100,000$ a share. It is not affordable for most investors, but it may be worth the price! Even on its own terms, the ratio of housing prices to income doesn't really measure affordability. A better measure would be the ratio of mortgage payments to income. Mortgage rates had fallen dramatically by the mid1990s, and consequently the ratio of mortgage payments on a constantquality new home to median family income fell steadily, from 0.35 in 1981 to 0.13 in $2003 .{ }^{14}$

The Local Market Monitor, which is widely cited in the popular press, uses a variation on the Case-Shiller approach to compare home prices across cities. For each city it calculates the ratio of relative home price (the ratio of a local home price index to a national home price index) to relative income (the ratio of average local income to average national income). The extent to which the current value of this ratio deviates from its historical average is used to measure whether homes are overpriced or underpriced.

National City Corporation uses a multiple regression model relating the ratio of housing prices to household income in a given urban area to historical prices, population density, mortgage rates, and the ratio of household income in the area to the national average. The amount by which actual market prices deviate from the prices predicted by the model is interpreted as the extent to which homes are overpriced or underpriced. Table 1 reports the percentage over- or undervaluation of homes in the ten locations that we will analyze later, as estimated by the Local Market Monitor and National City Corporation.

12. McCarthy and Peach (2004).

13. Case and Shiller (2003).

14. McCarthy and Peach (2004). 
Table 1. Others' Estimates of Overpricing or Underpricing of the Median Home, Summer 2005

Percent $t^{\mathrm{a}}$

\begin{tabular}{lcc}
\hline Market & National City Corp. & Local Market Monitor \\
\hline San Bernardino County & 65 & 56 \\
Los Angeles County & 54 & 61 \\
Orange County & 44 & 61 \\
San Mateo County & 35 & 35 \\
Boston & 18 & 29 \\
Chicago & 21 & 9 \\
New Orleans & 12 & -9 \\
Atlanta & 2 & -4 \\
Indianapolis & -5 & -19 \\
Dallas & -16 & -14 \\
\hline
\end{tabular}

Sources: DeKaser (2005), Local Market Monitor website.

a. Negative numbers indicate underpricing.

One problem with regression models is that the equations are likely to be misspecified, in that fundamental values are a highly nonlinear function of many variables. For example, Case and Shiller estimate the relationship between housing prices and personal income per capita between 1985 and 2002, but they omit interest rates from their model. ${ }^{15}$ If interest rates are included, both the mortgage rate (which affects the cash flow) and the homebuyers' required return (which is used to discount the cash flow) are needed, and the relationship is very nonlinear. Even more fundamentally, these models assume that past home prices were determined by fundamental factors (with a random error term), so that any systematic deviation of current prices from predicted values must be explained by current prices wandering away from fundamental values. However, if current market prices are higher than what multiple regression models predict using historical prices, it may be because past prices were consistently below fundamental values.

Indianapolis is an interesting example in that it has had relatively stable housing prices that are easy to "explain" with multiple regression models using historical prices and household income as independent variables. In the National City Corporation model, Indianapolis home prices have varied between 11 percent underpriced and 17 percent overpriced for the

15. Case and Shiller (2003). 
period studied, 1985-2005. Because the researchers "recommend treating valuation metrics between \pm 15 percent as 'fair value," " they conclude that Indianapolis homes have almost always been fairly valued. In reality, the regression model does not address the question of whether Indianapolis home prices are close to fundamental values. We will show later that they are almost certainly far below fundamental values.

Some economists, such as Edward Leamer, cite the fact that home prices have risen faster than rents as evidence of a bubble. ${ }^{16}$ John Krainer and Chishen Wei report that there has been a 30 percent real increase in home prices over the past decade and only a 10 percent real increase in rents over this same period, suggesting that prices are departing from fundamentals. ${ }^{17}$ The fundamental value of a home does depend on the anticipated rents, in the same way that the fundamental value of a bond or a share of stock depends on the present value of the cash flow from these assets. However, just as bond and stock prices are not a constant multiple of coupons and dividends, one should not expect the fundamental value of a home to be a constant multiple of rents. Among the many factors that affect the price-rent ratio are interest rates, risk premiums, growth rates, and tax laws (including property, income, and capital gains taxes). Thus, just as with price-earnings ratios in the stock market, price-rent ratios in the housing market can rise without signaling a bubble if, for example, interest rates fall or the anticipated rate of growth of rents rises.

In addition, the dwellings included in price indexes do not match the dwellings in rent indexes, so that the resulting comparison is of apples to oranges. ${ }^{18}$ The ratio of a home sale price index to a rent index can rise because the prices of homes in desirable neighborhoods increased more than did the rents of apartment buildings in less desirable neighborhoods. Or perhaps the quality of the average home in the price index has increased relative to the quality of the average property in the rent index. In any case, gauging fundamental value requires actual rent and sale price data, not indexes with arbitrary scales.

Similarly, Leamer compares median home sale prices with the owner's equivalent rent index constructed by the Bureau of Labor Statistics (BLS),

16. Edward E. Leamer, "Bubble Trouble? Your Home Has a P/E Ratio Too," UCLA Anderson Forecast, 2002.

17. Krainer and Wei (2004).

18. McCarthy and Peach (2004). 
and Charles Himmelberg, Christopher Mayer, and Todd Sinai compare rents for representative two-bedroom apartments with the repeat-sales index compiled by the Office of Federal Housing Enterprise Oversight (OFHEO). ${ }^{19}$ Even if the properties are comparable, they cannot gauge whether prices are high or low relative to rents because each study compares dollars to indexes.

\section{Buying Versus Renting}

Thus one is inevitably drawn back to the need to use actual rent data to estimate a home's fundamental value, which can then be compared with actual market prices. Because shelter can be obtained either by renting or by buying, the implicit cash flow from an owner-occupied home is the rent that would otherwise be paid to live in the home.

Buying and renting have sometimes been analyzed as demands for different commodities. Harvey Rosen wrote that "In many cases it may be difficult to rent a single unit with (say) a large backyard. Similarly, it may be impractical for a homeowner to contract for the kind of maintenance services available to a renter." ${ }^{20}$ A decade later Allen Goodman observed that "Until recently, it was easier to purchase small (large) amounts of housing by renting (owning). As a result, households with tastes for small (large) units would rent (buy)." 21

Today it is still true that rental and sale properties differ, on average, in location and attributes. But, at the margin, close substitutes are generally available. It is possible to buy a small condominium or to rent a house with a large yard. It is possible to buy or rent a small or a large house. Many households have the option of buying homes in communities that provide services very similar to those received by most renters.

Consequently, we view buying and renting as often being viable alternatives. If a household has the opportunity to buy or rent two very similar properties (perhaps even the same property), the relevant question is whether to pay for these housing services by buying the property or renting it. Admittedly, other considerations make renting and owning a different

19. Leamer (2002); Himmelberg, Mayer, and Sinai (2005).

20. Rosen and Rosen (1980, pp. 60).

21. Goodman (1988, pp. 335). 
experience. Renters may have different preferences (in paint colors and furnishings, for example) than do their landlords; renters cannot reap the full benefits of improvements they make to the property inside and out; and renters may have less privacy than do owners. These are all arguments for why owning is better than renting, and, to the extent they matter, our calculations underestimate the value of homeownership. Both renters and owners also confront uncertainty: renters about future rents-and about housing prices, if they might want to buy a home in the future; owners about future homeownership expenses and future housing prices if they might someday sell their home and move to a location with different rents and prices.

\section{Fundamental Value}

Rental savings are the central, but not the only, factor in determining the fundamental value of an owner-occupied home. One has to look at everything that affects the cash flow, including transaction costs, the down payment, insurance, maintenance costs, property taxes, mortgage payments, tax savings, and the proceeds if the home is sold at some point. Once the projected cash flow is estimated, homes can be valued in the same way as bonds, stocks, and other assets, by discounting the cash flow by the prospective buyer's required rate of return. Specifically, the net present value (NPV) of the entire cash flow, including the initial outlay, can be calculated as follows:

$$
\mathrm{NPV}=X_{0}+\frac{X_{1}}{(1+R)^{1}}+\frac{X_{2}}{(1+R)^{2}}+\frac{X_{3}}{(1+R)^{3}}+\cdots+\frac{X_{n}}{(1+R)^{n}} .
$$

Here $X_{0}$ is a negative number equal to the down payment and out-of-pocket closing costs; $X_{n}$ is the net amount received when the home is sold and the mortgage balance (if any) is paid off. The intervening cash flows are the rent that the owner would otherwise have to pay to live in this home, minus the mortgage payments and other expenses associated with home ownership, plus the value of nonfinancial factors (such as a desire for privacy). The rent and various expenses can be estimated from observed data. The intangibles must be assigned values by the household.

The required return $R$ depends on the rates of return available on other investments. The initial down payment ties up funds that could otherwise be invested in bonds, stocks, and other assets; as the years pass, the net rental savings free up funds that can be invested elsewhere. The required 
return depends on current interest rates, the degree of leverage, and uncertainty about the prospective cash flow. Our view is that the cash flow is less certain than that from highly rated bonds but more certain than that from a diversified stock portfolio, and that uncertainties about the cash flow are not strongly correlated with uncertainties about bond and stock returns.

A homebuyer can use the projected cash flow and a required rate of return to determine whether a home's NPV is positive or negative. If the NPV is positive, the home is indeed worth what it costs; if negative, renting is financially more attractive. Equation 1 can also be used to determine a prospective buyer's reservation price: the price that would make the NPV equal to zero. (Because mortgage payments and other components of the cash flow depend on the price of the home, the reservation price is not simply equal to the market price plus the NPV.) The reservation price can be interpreted as the fundamental value of the home, and the difference between the market price $P$ and the reservation price $P^{*}$ measures whether the home is overpriced or underpriced. What we will call the premium is this difference scaled by $P^{*}$ :

$$
\text { premium }=100\left(\frac{P-P^{*}}{P^{*}}\right) .
$$

One can also calculate the internal rate of return (IRR), which is the value of the required return for which the NPV equals zero. The cash flow from residential real estate is generally negative initially and positive in later years, with just one sign change, so that the NPV is a monotonically decreasing function of the required return. If so, the IRR identifies the breakeven required return for which the investor is indifferent about the investment, and the NPV is positive for any required return less than the IRR.

\section{Some Simple Intuition}

Consider a home that is purchased for cash and never sold. The present value of the future net cash flow $X_{t}$ from this home is

$$
\mathrm{PV}=\sum_{t=1}^{\infty} \frac{X_{t}}{(1+R)^{t}}
$$

Now suppose that the home is sold at a future date for a price equal to the present value of the cash flow beyond that date: 


$$
\mathrm{PV}=\sum_{i=1}^{n} \frac{X_{t}}{(1+R)^{t}}+\frac{P_{n}}{(1+R)^{n}},
$$

where

$$
P_{n}=\sum_{t=1}^{\infty} \frac{X_{n+t}}{(1+R)^{t}} .
$$

Substituting equation 4 into equation 3 gives equation 2 , so that this present value equation holds if the home is held forever or is sold at some future date for a price equal to the present value of the cash flow.

If the net cash flow is growing at a constant rate $g$, equation 2 simplifies to the standard dividend-discount model for stocks with constantly growing dividends:

$$
\begin{aligned}
\mathrm{PV} & =\sum_{t=1}^{\infty} \frac{X_{1}(1+g)^{t-1}}{(1+R)^{t}} \\
& =\frac{X_{1}}{R-g} .
\end{aligned}
$$

It is worth noting that seemingly small changes in $R$ or $g$ can have a substantial effect on the value of a home. Suppose that the net monthly cash flow is $\$ 1,000$ ( $\$ 12,000$ annually), the required annual after-tax rate of return is 9 percent, and the annual growth rate of the cash flow is 3 percent. Working with annual cash flows, one can calculate the home's value as

$$
\begin{aligned}
\mathrm{PV} & =\frac{X_{1}}{R-g} \\
& =\frac{\$ 12,000}{0.09-0.03} \\
& =\$ 200,000 .
\end{aligned}
$$

If the required rate of return falls to 6 percent, the value of the home doubles:

$$
\begin{aligned}
\mathrm{PV} & =\frac{X_{1}}{R-g} \\
& =\frac{\$ 12,000}{0.06-0.03} \\
& =\$ 400,000 .
\end{aligned}
$$


Peach has argued that the recent run-up in home prices is, in fact, a onetime adjustment of prices to lower interest rates. ${ }^{22}$

If the homebuyer is able to buy the home for a price $P_{0}$ that is equal to the present value of the cash flow, then the first-year required rate of return is equal to the current cash flow yield plus the cash flow's growth rate:

$$
\begin{aligned}
R & =\frac{X_{1}}{P_{0}}+\frac{P_{1}-P_{0}}{P_{0}} \\
& =\frac{X_{1}}{P_{0}}+g .
\end{aligned}
$$

Equation 6 has a very natural interpretation: the homebuyer's required rate of return equals the anticipated actual return, which is the current yield $X_{1} / P_{0}$ plus the anticipated rate of increase in the value of the house. If the buyer's expectations are realized, the buyer will earn the required rate of return. In this simple case one could use data on the current yield plus the projected rate of growth of the cash flow to estimate the buyer's anticipated rate of return.

In practice, matters are complicated by the fact that most buyers take on mortgages, which create leverage. Using an interest-only mortgage for simplicity, with a down payment $\lambda P_{0}$ and after-tax mortgage rate $R_{m}$, the amount invested is $\lambda P_{0}$ and the current cash flow is $X_{1}-R_{m}(1-\lambda) P_{0}$. Thus the leveraged first-year rate of return is

$$
\begin{aligned}
R_{L} & =\frac{X_{1}-R(1-\lambda) P_{0}}{\lambda P_{0}}+\frac{P_{1}-P_{0}}{\lambda P_{0}} \\
& =R_{m}+\frac{1}{\lambda}\left(\frac{X_{1}}{P_{0}}+\frac{P_{1}-P_{0}}{P_{0}}-R_{m}\right) .
\end{aligned}
$$

In words, the leveraged rate of return equals the mortgage rate plus the leverage factor $1 / \lambda$ times the difference between the unleveraged rate of return and the mortgage rate.

These simple models illustrate two general principles: the anticipated unleveraged after-tax rate of return is the cash flow yield plus the cash 
flow's anticipated growth rate; and the anticipated leveraged after-tax rate of return is higher or lower than the mortgage rate, depending on whether the unleveraged rate of return is higher or lower than the aftertax mortgage rate. In practice, the calculations are more complicated, because there are substantial transaction costs; the various elements of the cash flow do not necessarily grow at the same rate; and the amount of leverage changes over time as the value of the home grows and, with conventional amortized loans, the loan balance declines. Detailed cash flow projections are therefore needed to determine the NPV, the IRR, and the premium.

\section{Data}

To apply this approach, we gathered, from various multiple listing services, data for single-family homes that were purchased or rented in the summer of 2005 in the ten urban housing markets listed in table 1 and sought matches for each purchased home with a similar rented home. These cities were chosen to include a variety of geographic areas in the United States and various degrees of alleged housing market frothiness.

Los Angeles County has more than 10 million residents living in more than 200 cities and unincorporated areas. San Bernardino County has nearly 2 million residents living in an expanse of deserts and mountains stretching from the eastern edge of Los Angeles County to the Nevada border. Orange County is south of Los Angeles County and, although geographically small by Southern California standards, is the fifth most populous county in the United States. Because these three counties are each so geographically varied and heavily populated, we limited our study to several cities within each county that contain groups of relatively homogeneous homes: in Los Angeles County we chose Azusa, Bellflower, Claremont, Diamond Bar, Glendora, Hacienda Heights, La Puente, La Verne, Pacoima, Phillips Ranch, Pomona, Rosemead, San Dimas, Walnut, and West Covina; in San Bernardino County, Alta Loma, Chino Hills, Fontana, Montclair, Ontario, Rancho Cucamonga, Redlands, Rialto, San Bernardino, and Upland; and in Orange County, Buena Park, Fullerton, Huntington Beach, Irvine, La Habra, Laguna Beach, Laguna Hills, Lake Forest, Mission Viejo, Newport Beach, Orange, Rancho Santa Margarita, Santa Ana, Tustin, and Yorba Linda. 
Table 2. Rates of Increase in Population, Household Income, Home Sale Prices, and Rents, 1985-2005

Percent a year ${ }^{\mathrm{a}}$

\begin{tabular}{|c|c|c|c|c|c|c|}
\hline \multirow[b]{3}{*}{ Market } & \multicolumn{4}{|c|}{$1985-2005$} & & \\
\hline & \multirow[b]{2}{*}{ Population } & \multirow{2}{*}{$\begin{array}{c}\text { Median } \\
\text { household } \\
\text { income }\end{array}$} & \multirow[b]{2}{*}{ Sale prices ${ }^{\mathrm{b}}$} & \multirow[b]{2}{*}{ Rents $^{\mathrm{c}}$} & \multicolumn{2}{|c|}{ 1995-2005 } \\
\hline & & & & & Sale prices & Rents \\
\hline $\begin{array}{l}\text { San Bernardino } \\
\text { County }\end{array}$ & 3.07 & 2.79 & 6.65 & 3.81 & 10.43 & 2.73 \\
\hline $\begin{array}{c}\text { Los Angeles } \\
\text { County }\end{array}$ & 0.98 & 2.38 & 7.45 & 3.81 & 10.42 & 3.72 \\
\hline Orange County & 1.61 & 2.56 & 7.53 & 3.81 & 11.04 & 3.58 \\
\hline $\begin{array}{c}\text { San Mateo } \\
\text { County }\end{array}$ & 0.60 & 3.35 & 8.25 & 4.02 & 10.39 & 4.12 \\
\hline Boston & 0.14 & 3.48 & 6.58 & 4.14 & 10.02 & 4.49 \\
\hline Chicago & 0.10 & 2.62 & 6.11 & 3.97 & 6.11 & 3.26 \\
\hline New Orleans & -0.53 & 2.76 & 3.47 & n.a. & 5.51 & n.a. \\
\hline Atlanta & 1.76 & 2.84 & 4.21 & 2.44 & 5.34 & 2.31 \\
\hline Indianapolis & 0.54 & 3.07 & 4.03 & n.a. & 3.60 & n.a. \\
\hline Dallas & 1.36 & 2.59 & 1.88 & 2.48 & 4.20 & 2.92 \\
\hline
\end{tabular}

Sources: U.S. Census Bureau, OFHEO, and BLS data.

n.a., not available.

a. Data are means except where stated otherwise.

b. Quarterly OFHEO housing price indexes, annualized.

c. BLS owner's equivalent rent indexes, July of indicated year.

We obtained data for every city in San Mateo County, which is located just south of San Francisco; in the Dallas area, we looked only at the city of Dallas. For the other five markets, we looked at the major cities plus surrounding suburbs.

The areas included in our study, in other studies, and in various government indexes do not match perfectly. For example, the BLS owner's equivalent rent indexes lump together Los Angeles, Riverside, and Orange County, whereas the OFHEO housing price indexes put Riverside, San Bernardino, and Ontario together, even though Riverside is in Riverside County and San Bernardino and Ontario are in San Bernardino County. Similarly, National City Corporation gives separate valuation numbers for Los Angeles, Riverside, and Santa Ana (a large city in Orange County), and the Local Market Monitor gives a valuation for Los Angeles-Anaheim (Anaheim being another large city in Orange County) and for RiversideSan Bernardino.

Table 2 shows the annual percentage increases in population, median household income, OFHEO housing sale prices, and BLS owner's equiva- 
Figure 1. Housing Prices in Selected Urban Areas, 1976-2005

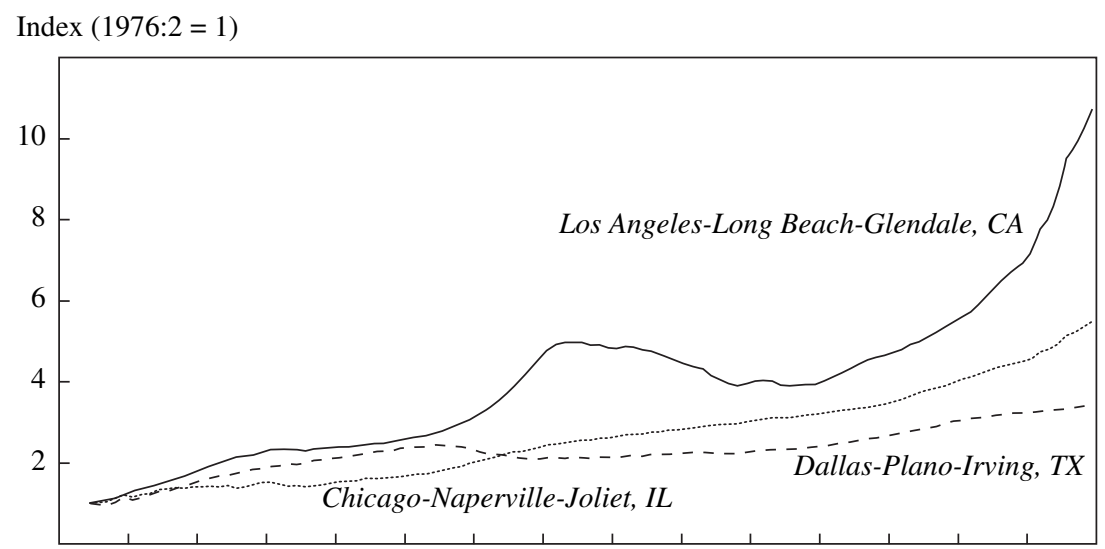

19771979198119831985198719891991199319951997199920012003

Source: U.S. Census Bureau, OFHEO house price indexes.

lent rents during the twenty years 1985-2005 and the sale price and rent indexes for the more recent ten years 1995-2005. For comparison, the average annual percentage increase in the U.S. consumer price index (CPI) was 3.02 percent for 1985-2005 and 2.49 percent for 1995-2005. Housing prices in the four California areas and Boston increased much faster than rents or the CPI, particularly during 1995-2005. Figure 1 shows time series data for housing prices back to 1976 for Los Angeles, Chicago, and Dallas.

In compiling our data in each of the ten markets, we allowed the matched rental and sale properties to differ by no more than 100 square feet in size, no more than one bedroom, and no more than half a bathroom. When the information was available, we also compared the homes' ages and styles (for example, ranch) and identified amenities (such as a swimming pool and the size of the garage). Because the three most important factors in real estate are location, location, and location, Yahoo! Maps was used to estimate the driving distance between properties (which could not exceed 1 mile) and to identify golf courses, parks, lakes, major highways, and other physical features that might add to or detract from a home's value. It was evident from these maps that driving distance often exaggerates the physical distance between homes; for example, two houses might have adjoining back yards but have a driving distance of 0.1 or even 0.2 mile. One 
Table 3. Mean Physical Characteristics of Sold and Rented Homes

\begin{tabular}{|c|c|c|c|c|c|c|}
\hline \multirow[b]{2}{*}{ Market } & \multicolumn{3}{|c|}{ Sold homes } & \multicolumn{3}{|c|}{ Rented homes } \\
\hline & $\begin{array}{c}\text { No. of } \\
\text { bedrooms }\end{array}$ & $\begin{array}{c}\text { No. of } \\
\text { bathrooms }\end{array}$ & $\begin{array}{l}\text { Square } \\
\text { feet }\end{array}$ & $\begin{array}{c}\text { No. of } \\
\text { bedrooms }\end{array}$ & $\begin{array}{c}\text { No. of } \\
\text { bathrooms }\end{array}$ & $\begin{array}{l}\text { Square } \\
\text { feet }\end{array}$ \\
\hline $\begin{array}{c}\text { San Mateo } \\
\text { County }\end{array}$ & 3.18 & 2.19 & 1,858 & 3.14 & 2.23 & 1,866 \\
\hline $\begin{array}{l}\text { Orange } \\
\text { County }\end{array}$ & 3.56 & 2.48 & 2,006 & 3.53 & 2.51 & 1,994 \\
\hline $\begin{array}{l}\text { Los Angeles } \\
\text { County }\end{array}$ & 3.46 & 2.12 & 1,754 & 3.45 & 2.08 & 1,753 \\
\hline Boston & 3.34 & 1.99 & 1,803 & 3.18 & 1.87 & 1,801 \\
\hline Chicago & 3.22 & 2.12 & 1,951 & 2.92 & 2.04 & 1,934 \\
\hline $\begin{array}{l}\text { San Bernardino } \\
\text { County }\end{array}$ & 3.50 & 2.36 & 1,830 & 3.49 & 2.38 & 1,827 \\
\hline Dallas & 2.83 & 1.68 & 1,484 & 2.87 & 1.72 & 1,470 \\
\hline New Orleans & 3.02 & 1.88 & 1,681 & 3.01 & 1.86 & 1,683 \\
\hline Atlanta & 3.42 & 2.32 & n.a. & 3.42 & 2.32 & n.a. \\
\hline Indianapolis & 3.26 & 2.41 & 1,758 & 3.28 & 2.42 & 1,756 \\
\hline
\end{tabular}

Source: Authors' calculations using data from various multiple listing services.

n.a., not available.

problem we encountered is that square footage is traditionally not reported in the Atlanta area; so we restricted our Atlanta matches to properties that have exactly the same number of bedrooms and bathrooms and that are no more than 0.2 mile driving distance from each other.

When there were multiple matches (for example, two sales to one similar rental), we used the best overall match in terms of square footage, distance, and so on. Occasionally, there was a perfect match in that a home that had been rented was sold, or a home was sold and then rented. Sometimes we found essentially adjacent tract houses that had been built within a year of each other and had exactly the same number of bedrooms and bathrooms and square feet. Unless there was a perfect match, the sale and rental properties surely differ in unknown ways (carpet versus wood floors, fireplace or no fireplace, paint colors), but we can hope that these differences average out over our sample, so that the single-family homes that were rented in the summer of 2005 were not systematically better or worse than the matched single-family homes that were sold during the same time period. If the rental properties are, on average, inferior to the sale properties, our calculations underestimate the returns to purchasing a home. Table 3 shows the mean physical characteristics of the properties in our sample; table 4 shows the means of the absolute value of the differ- 
Table 4. Mean Absolute Values of Differences in Physical Characteristics of Sold and Rented Homes

\begin{tabular}{|c|c|c|c|c|c|}
\hline \multirow[b]{2}{*}{ Market } & \multirow[b]{2}{*}{$\begin{array}{c}\text { No. of } \\
\text { matched pairs }\end{array}$} & \multicolumn{3}{|c|}{ Difference in } & \multirow[b]{2}{*}{$\begin{array}{c}\text { Distance apart } \\
\text { (miles) }\end{array}$} \\
\hline & & $\begin{array}{c}\text { No. of } \\
\text { bedrooms }\end{array}$ & $\begin{array}{c}\text { No. of } \\
\text { bathrooms }\end{array}$ & Square feet & \\
\hline $\begin{array}{c}\text { San Mateo } \\
\text { County }\end{array}$ & 90 & 0.21 & 0.17 & 42.0 & 0.40 \\
\hline $\begin{array}{l}\text { Orange } \\
\text { County }\end{array}$ & 116 & 0.16 & 0.08 & 32.8 & 0.31 \\
\hline $\begin{array}{l}\text { Los Angeles } \\
\text { County }\end{array}$ & 103 & 0.20 & 0.08 & 34.2 & 0.41 \\
\hline Boston & 85 & 0.42 & 0.28 & 61.6 & 0.61 \\
\hline Chicago & 85 & 0.49 & 0.50 & 64.6 & 0.75 \\
\hline $\begin{array}{l}\text { San Bernardino } \\
\text { County }\end{array}$ & 133 & 0.12 & 0.07 & 12.7 & 0.33 \\
\hline Dallas & 121 & 0.17 & 0.13 & 40.0 & 0.38 \\
\hline New Orleans & 125 & 0.16 & 0.10 & 45.7 & 0.42 \\
\hline Atlanta & 83 & 0.00 & 0.00 & n.a. & 0.04 \\
\hline Indianapolis & 103 & 0.12 & 0.03 & 29.3 & 0.20 \\
\hline
\end{tabular}

Source: Authors' calculations using data from various multiple listing services.

n.a., not available.

ences between the matched properties in the number of bedrooms, and the number of bathrooms, and square footage, as well as the average distance between the matched properties.

Our data were gathered in the fall of 2005 with the objective of gauging the housing market as of July 15, 2005. We consequently tried to find sale and rental transactions that occurred close to July 15, extending our search as far as May or September in order to obtain roughly 100 matches for each market. The increases in each area's BLS rents and OFHEO housing sale prices during 2005 were used to adjust all rents and sale prices to July 15 values. All of the data reported here refer to these adjusted prices. Table 5 shows the averages of the sale prices, monthly rents, and the ratio of the annual rent to the sale price for the matched properties. Also shown is the first-year cash flow (rent net of all estimated expenses), which will be explained shortly.

\section{Analysis}

In principle, we should use the appropriate parameter values for the marginal homebuyer in each area in July 2005. In practice, we do not know 
Table 5. Mean Initial Financial Characteristics of Sold and Rented Homes, July 2005 Dollars except where stated otherwise

\begin{tabular}{lccccc}
\hline Market & Sale price & $\begin{array}{c}\text { Monthly } \\
\text { rent }\end{array}$ & $\begin{array}{c}\text { Annual rent } \\
\text { as percent } \\
\text { of sale } \\
\text { price }\end{array}$ & $\begin{array}{c}\text { Monthly } \\
\text { cash flow } \\
\text { in first year }\end{array}$ & $\begin{array}{c}\text { Annual cash } \\
\text { flow as } \\
\text { percent of } \\
\text { sale price }\end{array}$ \\
\hline $\begin{array}{l}\text { San Mateo } \\
\quad \text { County }\end{array}$ & $1,200,020$ & 2,987 & 3.05 & $-2,698$ & -2.64 \\
$\begin{array}{l}\text { Orange } \\
\quad \text { County }\end{array}$ & 801,210 & 2,670 & 4.09 & $-1,266$ & -1.81 \\
$\begin{array}{l}\text { Los Angeles } \\
\quad \text { County }\end{array}$ & 572,408 & 2,128 & 4.55 & -632 & -1.24 \\
$\begin{array}{l}\text { Boston } \\
\text { Chicago }\end{array}$ & 570,342 & 2,216 & 4.89 & -634 & -1.13 \\
$\begin{array}{l}\text { San Bernardino } \\
\quad \text { County }\end{array}$ & 467,422 & 2,135 & 6.09 & -248 & -0.11 \\
$\begin{array}{l}\text { Dallas } \\
\text { New Orleans }\end{array}$ & 163,795 & 1,899 & 5.01 & -343 & -0.79 \\
$\begin{array}{l}\text { Atlanta } \\
\text { Indianapolis }\end{array}$ & 166,940 & 1,157 & 9.30 & & \\
\hline
\end{tabular}

Source: Authors' calculations using data from various multiple listing services.

all of the details—-such as whether the federal alternative minimum tax limits the marginal homebuyer's ability to deduct mortgage interest-and consequently we must use plausible values. Individual households using our model should use parameter values that reflect their particular situation.

The following national assumptions were used in estimating the cash flow: 20 percent down payment, thirty-year fixed-rate mortgage, 5.7 percent annual mortgage rate (the average thirty-year rate in mid-July 2005), buyer's closing costs equal to 0.5 percent of the sale price, annual maintenance costs equal to 1 percent of the price, a 28 percent marginal federal income tax rate, a 15 percent federal capital gains tax rate (on capital gains in excess of $\$ 500,000$ ), and a 6 percent seller's transaction cost if the home is sold. State and metropolitan-area data were used for property taxes, state income taxes, and home insurance. ${ }^{23}$

23. Most states have a fixed property tax rate that is applied to the amount by which the assessed value exceeds a homeowner's exemption. Massachusetts communities set property tax rates annually so that total tax revenue does not exceed the amount allowed by Proposition $2 \frac{1}{2}$. We consequently used actual 2004 property taxes for the Massachusetts homes in our data base that have these tax data to estimate the property taxes for those homes with missing data; we then assumed that property taxes will increase by 2.5 percent annually. Analogous methods were used for Indiana and Illinois properties. Assessed values 
The baseline model assumes a 3 percent annual increase in housing rents and expenses (roughly the recent historical and predicted rate of CPI inflation) and a 6 percent required after-tax rate of return. ${ }^{24}$

\section{Long Horizons}

One way to gauge whether market prices can be justified without unrealistic expectations about future prices is, as with dividend-discount models of stock prices, to assume that the investment is for keeps: that the buyer intends never to sell and is therefore unconcerned about future prices. Few people literally plan to hold stocks or homes forever, but this assumption allows us to determine whether the cash flow alone is sufficient to justify the current market price. We will use this approach but will also look at some finite horizons with modest assumptions about future prices.

When we need to focus on a single finite horizon for reasons of space, we often show a ten-year horizon - ten years being a round number that is somewhat longer than the eight years that U.S. Census survey data show to be the time the median homeowner has been living in his or her current residence, ${ }^{25}$ and somewhat shorter than the thirteen-year expected total residence time for homeowners estimated by Shoshana Anili, Jacob Hornik, and Miron Israeli. ${ }^{26}$ Eight years would understate the typical duration of residence, because people will stay in their current residence for an unknown additional period. The thirteen-year number is based on a convenient model with simplifying assumptions. Any homeowner using our model should look at horizons that are consistent with their own circumstances.

Households that move within a given market can effectively have the same very long horizons as those who stay put: for a homeowner who lives in the same housing market for sixty years and changes homes every

in California are initially based on the sale price and then assumed to increase by 2 percent annually, in accord with Proposition 13. For the other markets we assume that assessed values increase by 3 percent a year.

24. One of the authors presented some preliminary calculations at a meeting of twentyseven certified financial planners and asked them what required after-tax return they would use if they adopted our home valuation methodology; all answered either 5 or 6 percent. A New York Times comparison of buying and renting assumed a 4 percent after-tax return (David Leonhardt, "Is it Better to Buy or Rent?" The New York Times, September 25, 2005). If we had used 4 or 5 percent instead, this would have increased the estimated fundamental values.

25. Hansen (1998).

26. Anily, Hornik, and Israeli (1999). 
ten or fifteen years, movements in housing prices are not very important, since if the homeowner sells high (or low), he or she buys high (or low), too. Over very long horizons, if annual capital gains are substantially less than the required return, the rent savings from ownership will dominate the capital gains, and homebuyers should consequently focus on whether the rent savings justify the current market price. For example, with a 6 percent required annual rate of return and 3 percent annual price appreciation, the present value of the price declines by about 3 percent a year, and the present value of the price sixty years from now is only 18 percent of the current price. With 2 percent annual price appreciation, this present value is 10 percent; with 1 percent annual price appreciation, it is 6 percent. If the capital gains turn out to be large enough to matter, that is an added bonus from home ownership. Thus, unless households anticipate moving from a high-price area to a low-price area (or vice versa) or moving to a home of substantially different size from their present one, they can use a very long horizon in their analysis and focus on rental savings rather than price appreciation.

Once the focus is on the rental savings over a long horizon, a leveraged home is not as risky an investment as one might think. There are a variety of ways to think about this, including the low correlation of rents with wages, stock returns, bond returns, and other cash flows. Although buying a home may seem risky, not buying is risky, too, since a household that chooses to rent may find itself priced out of the housing market and having to pay variable rents for a very long time. Another way to think of the buy-versus-rent decision is to note that unlike stocks, bonds, and other conventional assets, a place to live is something that everyone needs and that one can pay for either with rent or with mortgage payments. Which is riskier: fixed mortgage payments or rent payments that change annually? Even with nothing down and infinite leverage, it could reasonably be argued that a fixed-rate mortgage is less risky than uncertain rent payments-in the same way that one might argue that a fixed-rate mortgage is less risky than a variable-rate mortgage.

\section{Where's the Bubble?}

Table 6 shows the median IRRs for each of our ten housing markets. The infinite horizon makes no assumptions about future prices; the finite horizons assume that housing prices rise by 3 percent a year. We will 
Table 6. Internal Rates of Return and Premiums at Different Horizons

\begin{tabular}{|c|c|c|c|c|c|c|}
\hline \multirow[b]{4}{*}{ Market } & \multicolumn{4}{|c|}{ Internal rate of return (percent a year) } & & \\
\hline & \multirow[b]{3}{*}{$\begin{array}{l}\text { Ten-year } \\
\text { horizon }^{\mathrm{a}}\end{array}$} & \multirow[b]{3}{*}{$\begin{array}{l}\text { Infinite } \\
\text { horizon }^{\mathrm{b}}\end{array}$} & \multicolumn{2}{|c|}{ Sixty-year horizon ${ }^{\mathrm{c}}$} & \multirow{2}{*}{\multicolumn{2}{|c|}{ Premium $^{\mathrm{d}}$ (percent) }} \\
\hline & & & \multirow{2}{*}{$\begin{array}{l}\text { Turnover } \\
\text { every } \\
\text { ten years }\end{array}$} & \multirow{2}{*}{$\begin{array}{c}\text { Turnover } \\
\text { every } \\
\text { fifteen years }\end{array}$} & & \\
\hline & & & & & $\begin{array}{c}\text { Ten-year } \\
\text { horizon }\end{array}$ & $\begin{array}{l}\text { Infinite } \\
\text { horizon }\end{array}$ \\
\hline $\begin{array}{l}\text { San Mateo } \\
\text { County }\end{array}$ & 3.51 & 4.61 & 3.85 & 4.61 & 42 & 54 \\
\hline $\begin{array}{l}\text { Orange } \\
\text { County }\end{array}$ & 6.37 & 5.90 & 5.32 & 5.90 & -4 & 2 \\
\hline $\begin{array}{c}\text { Los Angeles } \\
\text { County }\end{array}$ & 7.86 & 6.62 & 6.1 & 6.62 & -17 & -11 \\
\hline Boston & 7.66 & 6.66 & 6.18 & 6.66 & -15 & -12 \\
\hline Chicago & 8.76 & 7.18 & 6.71 & 7.18 & -23 & -17 \\
\hline $\begin{array}{l}\text { San Bernardino } \\
\text { County }\end{array}$ & 9.10 & 7.33 & 6.84 & 7.33 & -26 & -20 \\
\hline Dallas & 16.23 & 13.04 & 12.48 & 13.04 & -43 & -40 \\
\hline New Orleans & 16.18 & 13.01 & 12.44 & 13.01 & -49 & -46 \\
\hline Atlanta & 21.46 & 18.42 & 17.98 & 18.42 & -56 & -53 \\
\hline Indianapolis & 23.56 & 21.21 & 20.88 & 21.21 & -68 & -65 \\
\hline
\end{tabular}

Source: Authors' calculations using data from various multiple listing services.

a. Homebuyer is assumed to sell the home after ten years; market price is assumed to rise at 3 percent a year.

b. Homebuyer is assumed to keep the home forever.

c. Homebuyer is assumed to sell the home and purchase another in the same market every ten or fifteen years over a sixty-year period, incurring a 6 percent transaction cost each time.

d. Percent by which the sale price exceeds fundamental value, assuming a 6 percent required rate of return.

show later that if prices do not increase by 3 percent a year, this will have a significant effect on the ten-year IRRs but little effect on the sixty-year IRRs. The sixty-year horizon (a long horizon evenly divisible by ten and fifteen) assumes that the household changes homes every ten or fifteen years and incurs a 6 percent transaction cost each time it moves (unlikely though it may seem that the industry will be able to maintain such high transaction costs for another sixty years).

Figure 2 shows box plots for each of the ten markets of each matched pair's premium (the percentage by which the market price exceeded the reservation price) with an infinite horizon. The last two columns of table 6 show the median premium with an infinite and a ten-year horizon, which can be compared with the assessments of housing prices for these same ten markets by National City Corporation and Local Market Monitor (table 1). By our reckoning, San Mateo's bubble ranking should be higher than their estimates indicate, and San Bernardino's much lower, and among the bottom four cities, it is Indianapolis, not Dallas, that is the 
Figure 2. Variation in Premiums in Ten Housing Markets ${ }^{\mathrm{a}}$

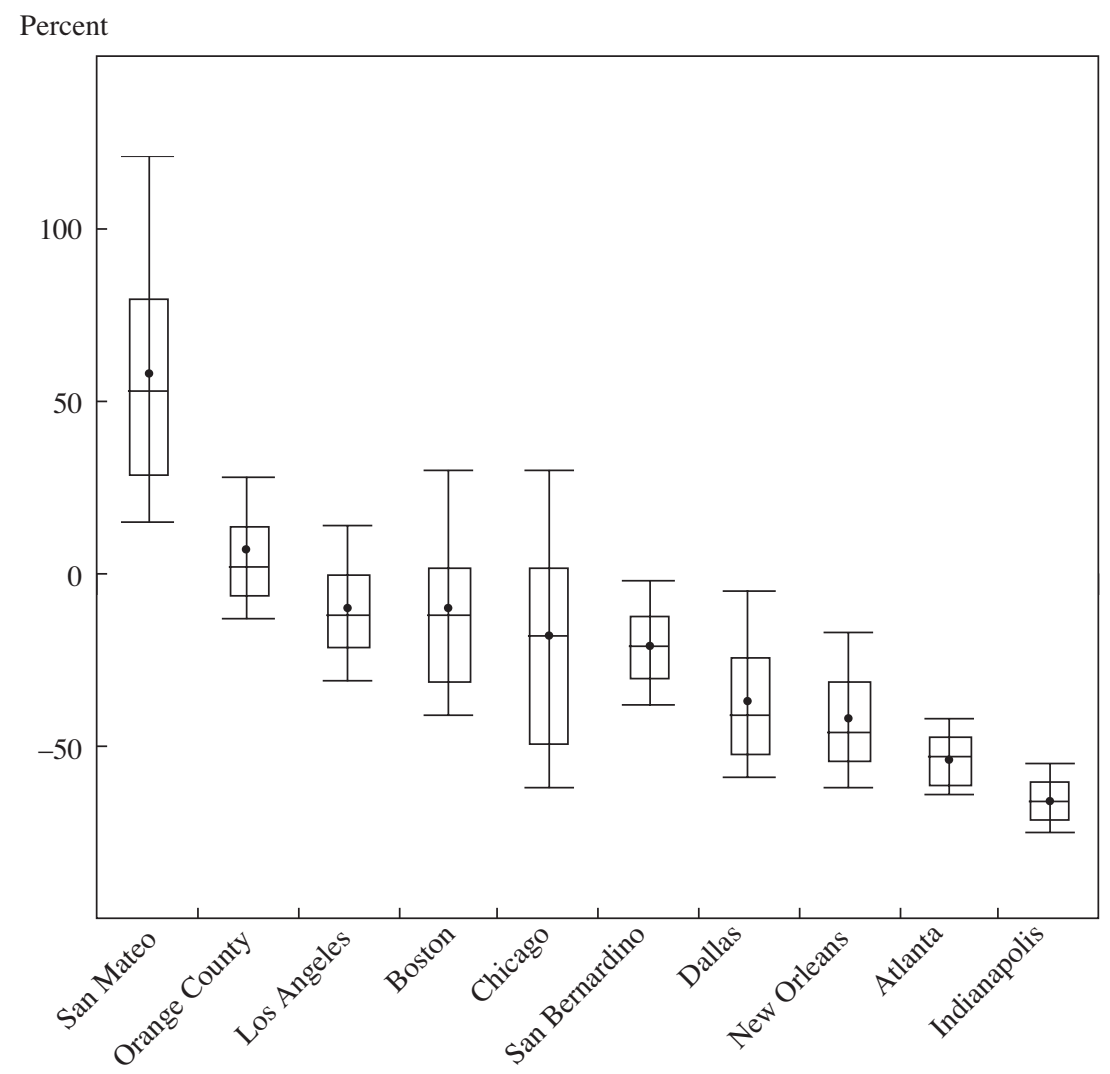

Source: Authors' calculations using data from various multiple listing services.

a. Premiums assume an infinite horizon. The box indicates the 25 th and 75 th percentiles; the outer lines indicate the 10 th and 90th percentiles. The median is indicated by a solid line and the mean by a dot.

biggest bargain. More generally, whereas National City Corporation and Local Market Monitor consider most of these ten markets to be overpriced, based largely on the recent increases in home prices, our comparison of 2005 prices with fundamental values indicates that most are fairly priced or underpriced.

Under our baseline assumptions only San Mateo seems bubbly, with a median IRR of 4.61 percent a year for an infinite horizon and 3.51 percent for a ten-year horizon. For a homebuyer with a 6 percent required return, 
the median San Mateo property is 54 percent overpriced with an infinite horizon and 42 percent overpriced with a ten-year horizon. Orange County seems to be fairly valued, and Los Angeles, San Bernardino, Boston, and Chicago are all somewhat underpriced. Home prices in Dallas, New Orleans, Atlanta, and Indianapolis appear to be substantially below fundamental values.

Table 5 above showed that, in Indianapolis, the average monthly rent is about half what it is in Boston, but sale prices are one-fourth Boston levels, and the average initial monthly cash flow is positive in Indianapolis but negative in Boston. The average ratio of initial annual cash flow to sale price is 3.32 percent in Indianapolis and, with a 20 percent down payment, the ratio of the cash flow to the down payment (not shown) is five times the numbers shown in the last column of table 5. With these favorable fundamentals, table 6 shows that Indianapolis housing prices are only about a third of fundamental values.

New Orleans is a particularly interesting case, in that it vividly demonstrates that we are not attempting to time the market or predict housing prices. When one estimates the fundamental value of a stock, the proper question is not whether the price will be higher tomorrow than it is today, but whether, given currently available information, the projected cash flow is sufficient to justify the market price, in the sense that an investor would be happy to pay today's price in order to receive the anticipated cash flow. The same is true here. Our objective is to estimate, based on information available in the summer of 2005, just before Hurricane Katrina, whether the projected cash flow from the homes we looked at is sufficient to justify market prices. Accounting fraud, oil discoveries, hurricanes, and other unexpected events may well lead to substantial revisions in the fundamental values of stocks and of real estate.

Orange County is also interesting in that, as figure 2 shows, there appear to be almost as many homes that sold at a discount from fundamental value as sold at a premium. Whereas it may be hard to find a bargain in San Mateo and easy to find one in Indianapolis, homebuyers in Orange County can find plenty of properties that are priced above and plenty that are below fundamental values. Of course, in every city there are different degrees of underpricing and overpricing, and prospective home buyers should make their own estimates of the rental savings and other components of the cash flow and apply their own personal required return in order to estimate the fundamental value of the homes they are considering purchasing. 


\section{Predicting Future Prices}

Again, our objective here is not to predict future movements in housing prices, but rather to gauge whether plausible projections of cash flow are sufficient to justify current prices. This is most obvious in the calculations that assume that the homeowner buys for keeps. For the finite-horizon calculations, we assume modest rates of price appreciation that are consistent with predicted rates of inflation and historical increases in home prices.

One might temper these price projections by a comparison of fundamental values with current market prices. Someone who believes that market prices will equal fundamental values at some point in the future might be more optimistic about the future rate of increase of housing prices in Indianapolis than in San Mateo. Similarly, if one is willing to assume that market prices will converge to fundamental values by the time the homeowner is ready to sell, then one could project fundamental values at that future date. For instance, one could predict rents, mortgage rates, and the model's other parameters ten years from now, use these parameter values to predict fundamental values ten years from now, and then predict that market prices ten years from now will equal fundamental values at that time. We have not done this because of our deep skepticism about whether the residential real estate market has any effective mechanism for tightly anchoring market prices to fundamental values. We will report evidence later that residential real estate prices can remain far from fundamental values for a substantial period.

\section{Stricter Matching Criteria}

Table 7 shows the median values of the premium in each market for more stringent matching criteria. The same-home data are the smallest samples but also the purest matches, in that these properties could literally have been either purchased or rented in the summer of 2005. The only weakness in these data is if there were any special circumstances, such as a below-market rent for someone who agreed to repaint the home, or if the home was purchased and major renovations were made before it was rented. The perfect-match data include both the same-homes data and homes that are quantitatively identical (same number of bedrooms, bathrooms, and square footage) and virtually adjacent. The close-match data expand the sample to include properties that differ in square footage by up to fifty feet and that are less than 0.5 mile apart. 


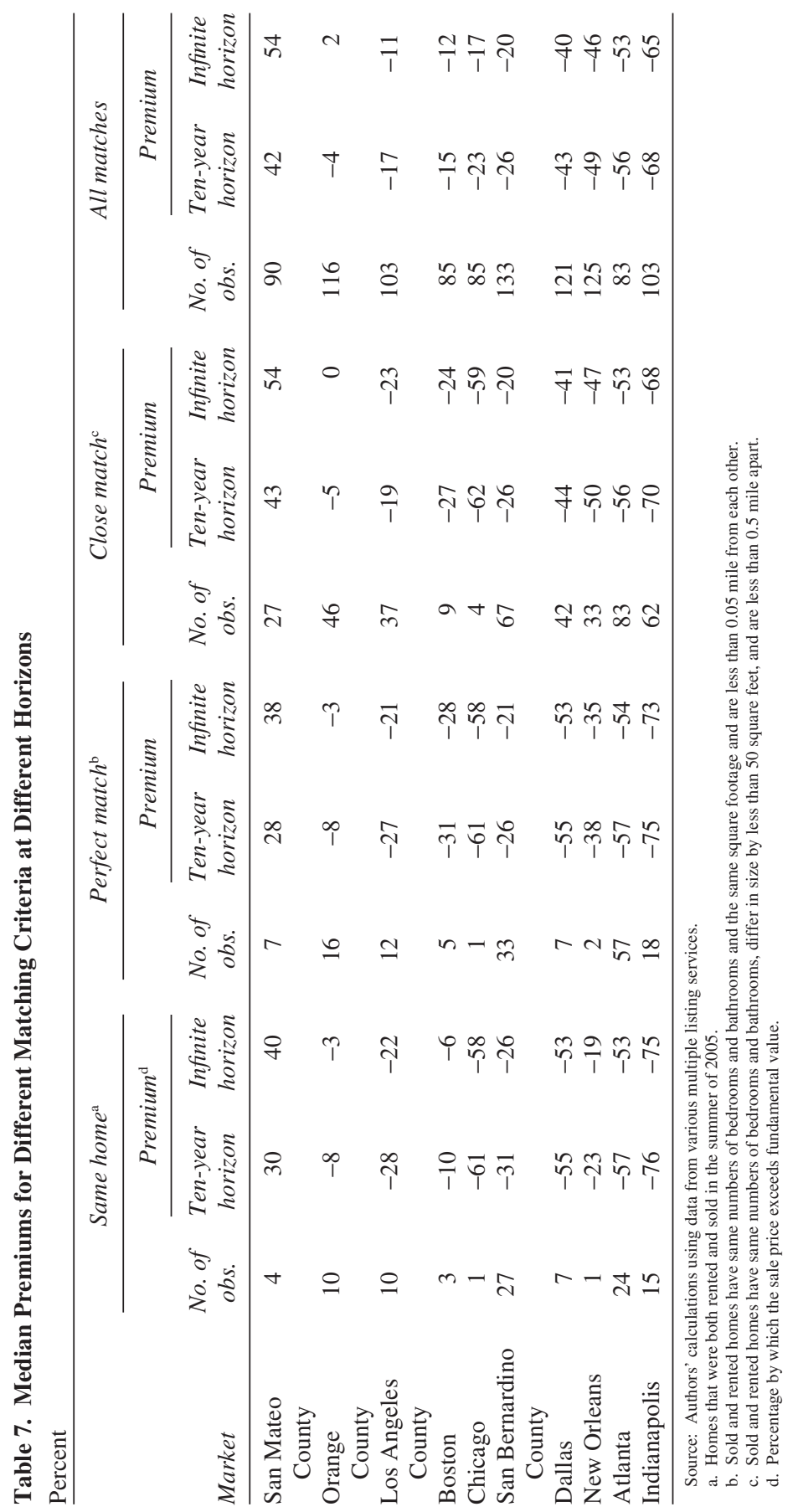


Table 8. Median Premiums for Different Growth Rates of Rents and Prices ${ }^{\mathrm{a}}$

Premium (percent by which home sale price exceeds fundamental value) when

\begin{tabular}{|c|c|c|c|c|c|c|c|c|c|c|c|c|}
\hline \multirow[b]{2}{*}{ Market } & \multicolumn{4}{|c|}{$\begin{array}{c}\text { Annual rent } \\
\text { growth }=2 \% \text { and } \\
\text { annual home price } \\
\text { growth is }\end{array}$} & \multicolumn{4}{|c|}{$\begin{array}{c}\text { Annual rent } \\
\text { growth }=3 \% \text { and } \\
\text { annual home price } \\
\text { growth is }\end{array}$} & \multicolumn{4}{|c|}{$\begin{array}{c}\text { Annual rent } \\
\text { growth = 4\% and } \\
\text { annual home price } \\
\text { growth is }\end{array}$} \\
\hline & $0 \%$ & $3 \%$ & $6 \%$ & NA & $0 \%$ & $3 \%{ }^{\mathrm{b}}$ & $6 \%$ & $\mathrm{NA}^{\mathrm{b}}$ & $0 \%$ & $3 \%$ & $6 \%$ & NA \\
\hline $\begin{array}{c}\text { San Mateo } \\
\text { County }\end{array}$ & 169 & 50 & -62 & 142 & 152 & 42 & -63 & 54 & 137 & 3 & -65 & -10 \\
\hline $\begin{array}{l}\text { Orange } \\
\text { County }\end{array}$ & 74 & 1 & & 50 & 65 & 4 & & 2 & 6 & -9 & -72 & -37 \\
\hline $\begin{array}{l}\text { Los Angeles } \\
\text { County }\end{array}$ & 52 & -13 & -77 & 29 & 44 & -17 & -78 & -11 & 36 & -22 & -79 & -44 \\
\hline Boston & 54 & -11 & -77 & 29 & 45 & -15 & -78 & -12 & 38 & -20 & -79 & -45 \\
\hline Chicago & 36 & -18 & -78 & 19 & 29 & -23 & -79 & -17 & 23 & -27 & -80 & -48 \\
\hline $\begin{array}{l}\text { San Bernardino } \\
\text { County }\end{array}$ & 36 & -22 & -80 & 15 & 29 & -26 & -81 & -20 & 23 & -24 & -81 & -50 \\
\hline Dallas & -13 & -40 & -76 & -15 & -17 & -43 & -77 & -40 & -21 & -46 & -78 & -62 \\
\hline New Orl & -13 & -46 & -84 & -25 & -17 & -49 & -85 & -46 & -21 & -51 & -85 & -65 \\
\hline & -29 & -54 & -8 & -35 & -32 & -5 & -85 & -53 & -35 & -58 & -85 & -69 \\
\hline Indianapolis & -37 & -66 & -93 & -52 & -41 & -68 & -93 & -65 & -44 & -69 & -94 & -77 \\
\hline
\end{tabular}

Source: Authors' calculations using data from various multiple listing services.

a. Rates of 0,3 , and 6 percent are over a ten-year horizon; "NA" (not applicable) indicates an infinite horizon where no assumption is made regarding future home price growth.

b. Baseline case.

The results are generally consistent across matching criteria, with a tendency (except for the very small Boston and New Orleans samples) for the stricter criteria to reduce the premium. In Indianapolis, for example, with an infinite horizon, the median home in the full sample of 103 matched pairs sold for 65 percent below its reservation price, whereas the median home among the twenty-three homes that were both sold and rented had a market price 75 percent below its reservation price.

\section{Risks}

We can gauge the robustness of our results by varying our key assumptions. For example, table 8 shows the median values of the premium for different future growth rates of rents and sale prices. Annual rent growth rates of 2, 3, and 4 percent are roughly the historical range shown in ta- 
ble 2 across these ten markets. For each of these rent growth rates, we report results for an infinite horizon with no assumptions about future housing prices, and for ten-year horizons with assumed annual price increases of 0 percent, 3 percent, and 6 percent.

As expected, the faster the future growth of rent, the more financially attractive is purchasing a home in all of these areas. Boston, Chicago, and the four California areas all experienced annual rent increases of approximately 4 percent over 1985-2005. The last column of table 8 shows that if this were to continue indefinitely, home prices in the summer of 2005 would be fully justified in all of these areas, even San Mateo. For ten-year horizons with 4 percent annual rent growth, sale prices would have to increase by more than 3 percent a year to justify San Mateo prices. At the other end of the spectrum, sale prices in Dallas, Indianapolis, Atlanta, and New Orleans are financially justified even with 2 percent annual rent growth and zero price growth. Even if Indianapolis rents and sale prices were not to grow at all, the IRR would be 15.6 percent with a ten-year horizon and 13.2 percent with an infinite horizon (not shown).

For another way of looking at the data, figure 3 shows the median breakeven required returns - the IRRs - in six markets for a homebuyer with an infinite horizon and different annual growth rates of rent. To unclutter the graph, we have omitted New Orleans (which is very similar to Dallas) and Boston, Chicago, and Orange County (which would all lie between San Bernardino and San Mateo in the figure). The vertical line in the figure shows the IRRs for the 3 percent annual rent growth assumed in the baseline case. For each rent growth rate, the fundamental value is more than the market price if the homebuyer's required rate of return is below the curve for that market. In Indianapolis and Atlanta, market prices are below fundamental values even with 1 percent long-run annual rent growth and double-digit after-tax required returns. In San Mateo, homebuyers need to assume long-run 3.8 percent annual rent growth or have a required return below 6 percent in order for market prices to be below fundamental values.

\section{Capital Gains Matter in the Short Run, Rent Savings in the Long Run}

National City Corporation and the Local Market Monitor identify San Bernardino County housing as having been 65 percent and 56 percent overpriced, respectively, in the summer of 2005 (table 1). Figure 4 shows our calculated median IRRs with long-run annual price growth rates ranging 
Figure 3. Breakeven Required Return for Different Growth Rates of Rent, Selected Housing Markets

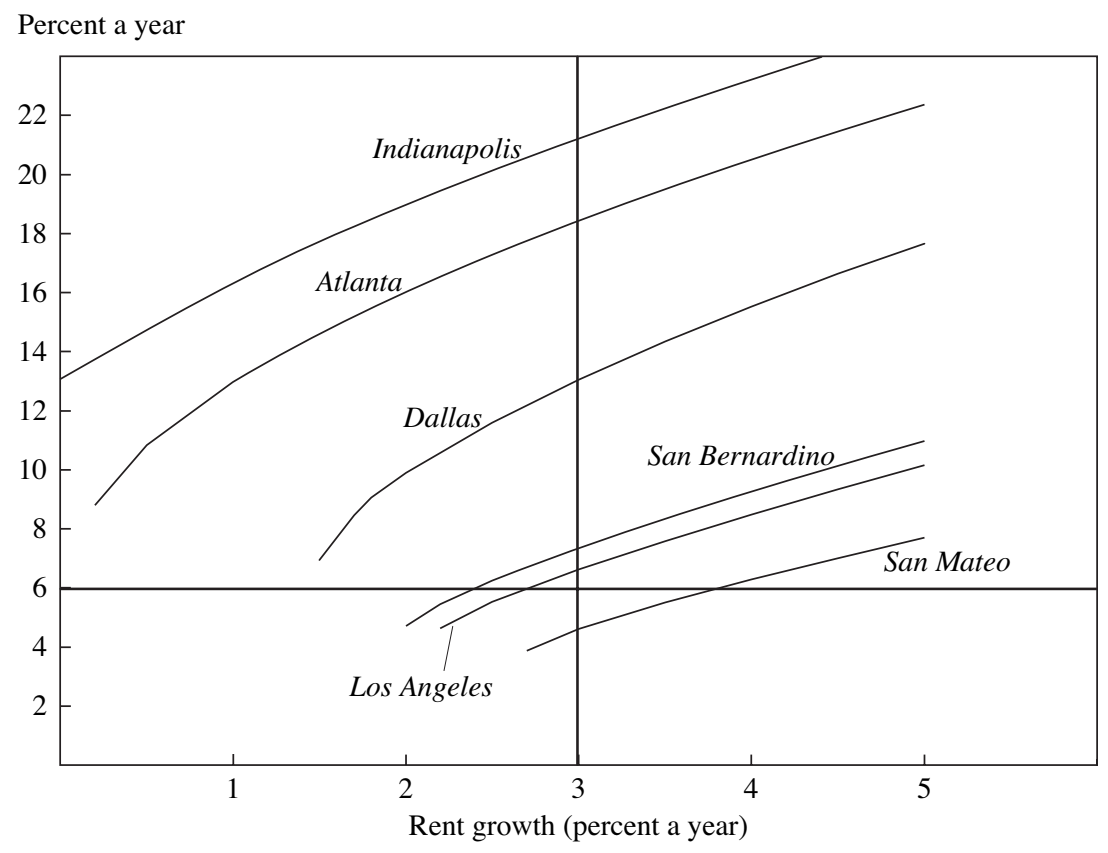

Source: Authors' calculations using data from various multiple listing services.

from zero to 3 percent. (To show more detail, the IRRs with a one-year horizon are omitted; they range from -18.3 percent with 3 percent annual price growth to -35.6 percent with zero price growth.) As the figure shows, over long horizons the IRRs are not very sensitive to price growth rates in this range. Figure 5, in contrast, shows that the long-run IRRs are sensitive to the assumed long-run rate of growth of rents. Thus shortfalls in price appreciation are more important in the short run, and shortfalls in rent growth are more important in the long run.

We have not attempted to use a structural model to forecast rents. Such a model would no doubt reflect demand factors, such as population and income growth, and supply factors, such as the cost of construction and the price of land (reflecting population density and zoning laws). In areas where market values exceed construction costs plus the price of land (Tobin's $q$ is greater than 1), one could reasonably anticipate increases in the housing 
Figure 4. San Bernardino County: Median Internal Rates of Return for Different Price Growth Assumptions and Horizons ${ }^{\mathrm{a}}$

Internal rate of return (percent a year)

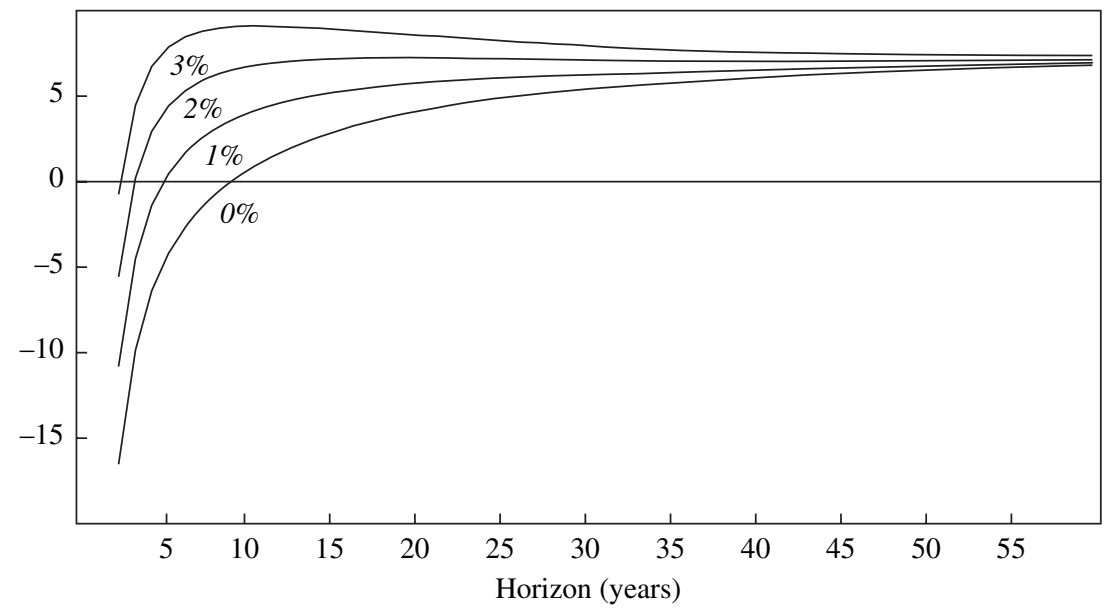

Source: Authors calc ulations using data from various multiple listing services. a. Calculations assume 3 percent annual rent growth.

Figure 5. San Bernardino County: Median Internal Rates of Return for Different Rent Growth Assumptions and Horizons ${ }^{\mathrm{a}}$

Internal rate of return (percent a year)

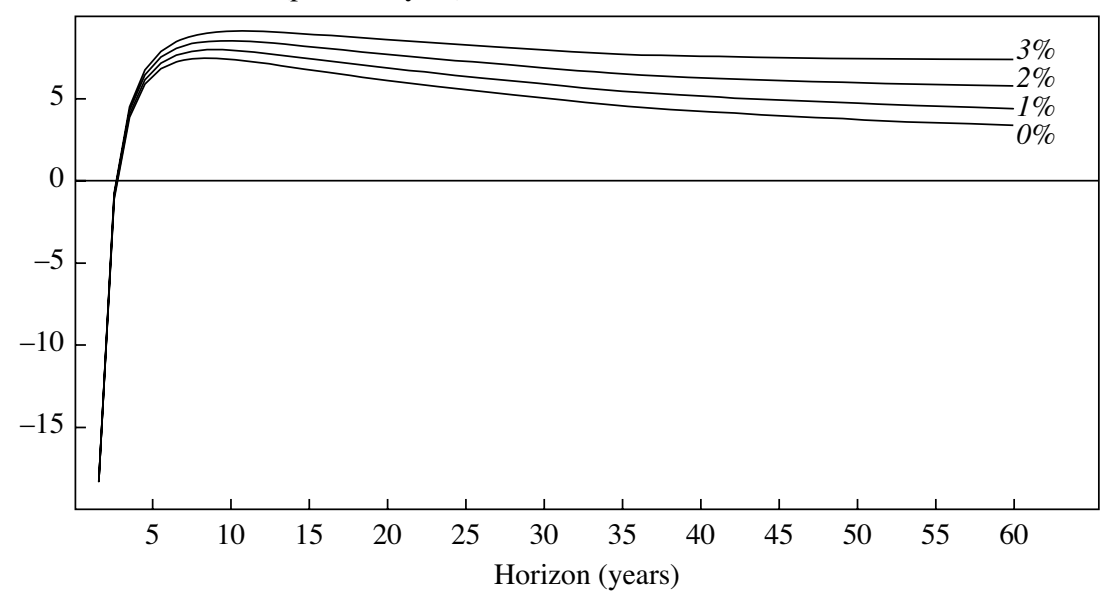

Source: Authors' calculations using data from various multiple listing services. a. Calculations assume 3 percent annual price growth. 
Table 9. Median Premiums for Different Mortgage Rates, Required Returns, and Horizons

Percent

\begin{tabular}{|c|c|c|c|c|c|c|}
\hline \multirow[b]{3}{*}{ Market } & \multicolumn{6}{|c|}{ Premium $^{\mathrm{a}}$ on home sale price when } \\
\hline & \multicolumn{2}{|c|}{$\begin{array}{l}\text { Annual mortgage } \\
\text { rate }=4.7 \%, \\
\text { required rate of } \\
\text { return }=5.3 \% \text {, } \\
\text { and horizon is }\end{array}$} & \multicolumn{2}{|c|}{$\begin{array}{l}\text { Annual mortgage } \\
\text { rate }=5.7 \% \text {, } \\
\text { required rate of } \\
\text { return }=6.0 \% \text {, } \\
\text { and horizon is }\end{array}$} & \multicolumn{2}{|c|}{$\begin{array}{c}\text { Annual mortgage } \\
\text { rate }=\text { required } \\
\text { rate of } \\
\text { return }=6.7 \% \text {, } \\
\text { and horizon is }\end{array}$} \\
\hline & Ten years & Infinite $^{\mathrm{b}}$ & Ten years & Infinite & Ten years & Infinite \\
\hline San Mateo County & 4 & 22 & 42 & 54 & 70 & 86 \\
\hline Orange County & -23 & -18 & -4 & 2 & 14 & 22 \\
\hline Los Angeles County & -35 & -30 & -17 & -11 & 0 & 6 \\
\hline Boston & -34 & -31 & -15 & -12 & 3 & 6 \\
\hline Chicago & -39 & -33 & -23 & -17 & -3 & -1 \\
\hline San Bernardino County & -42 & -37 & -26 & -20 & -7 & -4 \\
\hline Dallas & -52 & -49 & -43 & -40 & -33 & -32 \\
\hline New Orleans & -60 & -56 & -49 & -46 & -37 & -36 \\
\hline Atlanta & -64 & -60 & -56 & -53 & -47 & -45 \\
\hline Indianapolis & -76 & -73 & -68 & -65 & -59 & -58 \\
\hline
\end{tabular}

Source: Authors' calculations using data from various multiple listing services.

a. Percentage by which the market price exceeds fundamental value.

b. No assumption is made regarding price growth.

stock. Indeed, a comparison of housing prices, net of land, with construction costs might be used to predict the amount of future home building. However, in highly desirable areas with limited land and restrictive zoning laws, the site value may be a large part of a house's market value, and a comparison of changes in market prices and construction cost indexes might be an unreliable measure of the profitability of building new homes.

\section{Interest Rates Matter}

Although our objective is not to forecast housing prices, we can assess the extent to which changes in mortgage rates and required returns would affect reservation prices. Table 9 compares the hypothetical premiums across markets for mortgage rates of 4.7 percent, 5.7 percent (again, the actual average value of thirty-year mortgage rates as of July 2005), and 6.7 percent. Since required returns are on an after-tax basis, as the beforetax mortgage rate goes up or down by 1 percentage point, we change the after-tax required return by 0.7 percentage point (based on a 28 percent marginal federal income tax rate). San Mateo looks pricey even with a 
4.7 percent mortgage rate and a 5.3 percent after-tax required return. Dallas, Indianapolis, Atlanta, and New Orleans look cheap even with a 6.7 percent mortgage rate and a 6.7 percent after-tax required return.

\section{Monte Carlo Simulations}

For another kind of sensitivity analysis, we can incorporate stochastic changes in rent and sale prices into the model and use Monte Carlo simulations to estimate probability distributions for the NPVs. We illustrate this approach here with a matched pair of Southern California houses that are directly across the street from each other. Both are 2,200-square-foot, fourbedroom, three-bath, two-story houses built in 1981 on 5,600-square-foot lots. From the outside the main difference appears to be that one is painted a lighter color than the other. One was leased for $\$ 2,116$ a month in the summer of 2005; the other sold for $\$ 571,098$. The NPVs using a 6 percent required return are $\$ 25,539$ with a ten-year horizon and $\$ 57,989$ with an infinite horizon.

Because our matched rent-price data are unique, there are no directly comparable historical data that can be used to estimate the means, variances, and covariances of rent and sale prices that we need for our simulations. Instead we use Los Angeles-area BLS and OFHEO indexes to give ballpark estimates.

The columns for the fixed-rate mortgage in table 10 show the median NPVs (using a 6 percent after-tax required rate of return) and the probabilities that the NPV will be less than $-\$ 50,000$ and less than $-\$ 100,000$. (An NPV of $-\$ 50,000$ reflects an after-tax IRR of approximately 1.8 percent over a ten-year horizon and 5.5 percent over an infinite horizon; an NPV of $-\$ 100,000$ reflects an after-tax IRR of approximately -5.2 percent over a ten-year horizon and 5.0 percent over an infinite horizon.) Figure 6 shows the corresponding complete estimated probability distribution (the curve labeled "Fixed-rate mortgage") for the NPV with a ten-year horizon (top panel) and with an infinite horizon. With a ten-year horizon, there is an estimated 37.8 percent chance that the NPV will be negative (an IRR below 6 percent) and a 11.1 percent chance that the IRR will be negative. With an infinite horizon, there is an estimated 16.7 percent chance that the NPV will be negative and zero chance that the IRR will be negative.

The above calculations assume that the homebuyer chooses a thirtyyear mortgage with a fixed interest rate. Many homebuyers instead choose variable-rate mortgages, perhaps because the initial interest rate is less 
Table 10. Net Present Values from Stochastic Simulations with Fixed and Variable Mortgage Rates and Different Horizons ${ }^{a}$

\begin{tabular}{|c|c|c|c|c|c|c|}
\hline \multirow{3}{*}{$\begin{array}{l}\text { Horizon } \\
\text { (years) }\end{array}$} & \multicolumn{3}{|c|}{ Fixed-rate mortgage } & \multicolumn{3}{|c|}{ Variable-rate mortgage } \\
\hline & \multirow{2}{*}{$\begin{array}{c}\text { Median } \\
N P V \\
\text { (dollars) }\end{array}$} & \multicolumn{2}{|c|}{$\begin{array}{l}\text { Probability that } \\
N P V \text { is less than }\end{array}$} & \multirow{2}{*}{$\begin{array}{c}\text { Median } \\
\text { NPV } \\
\text { (dollars) }\end{array}$} & \multicolumn{2}{|c|}{$\begin{array}{l}\text { Probability that } \\
\text { NPV is less than }\end{array}$} \\
\hline & & $-\$ 50,000$ & $-\$ 100,000$ & & $-\$ 50,000$ & $-\$ 100,000$ \\
\hline 1 & $-28,413$ & 0.02 & 0.00 & $-28,420$ & 0.02 & 0.00 \\
\hline 2 & $-20,337$ & 0.07 & 0.00 & $-20,544$ & 0.08 & 0.00 \\
\hline 3 & $-12,856$ & 0.11 & 0.00 & $-13,116$ & 0.12 & 0.00 \\
\hline 4 & $-5,937$ & 0.13 & 0.01 & $-6,055$ & 0.15 & 0.01 \\
\hline 5 & 467 & 0.15 & 0.01 & 633 & 0.17 & 0.02 \\
\hline 10 & 25,693 & 0.16 & 0.04 & 27,640 & 0.18 & 0.06 \\
\hline 15 & 41,903 & 0.15 & 0.04 & 45,061 & 0.17 & 0.06 \\
\hline 20 & 51,631 & 0.13 & 0.03 & 54,084 & 0.15 & 0.05 \\
\hline 25 & 53,346 & 0.11 & 0.02 & 55,886 & 0.13 & 0.04 \\
\hline 30 & 50,176 & 0.10 & 0.01 & 54,070 & 0.12 & 0.04 \\
\hline Infinite & 58,290 & 0.03 & 0.00 & 61,190 & 0.07 & 0.01 \\
\hline
\end{tabular}

Source: Authors' calculations using multiple listing service data. a. See the appendix for details of the simulations.

than that on a fixed-rate mortgage of the same term. There are, of course, a plethora of fixed-rate and variable-rate options. For example, interestonly mortgages maintain more leverage than do amortizing mortgageswhich is good if the unleveraged return exceeds the after-tax mortgage rate but bad otherwise. We will focus on the cash flow risk inherent in a variable-rate mortgage by assuming that the initial mortgage rate is 5.7 percent, the same as with our thirty-year fixed-rate mortgage, and that the mortgage rate is adjusted every twelve months based on the average interest rate on one-year Treasury securities during the most recent month, with a 10 percent maximum interest rate and a 2-percentage-point cap on the annual change in the interest rate. Every time the mortgage rate is changed, the loan is amortized over the remaining years of the mortgage.

The variable-rate column in table 10 shows the median NPVs over various horizons for Monte Carlo simulations of the model described in the appendix. Figure 6 shows that with a ten-year horizon (top panel) there is an estimated 37.8 percent chance that the NPV will be negative (an IRR below 6 percent) and a 12.4 percent chance that the IRR will be negative; with an infinite horizon there is an estimated 20.7 percent chance that the NPV will be negative and zero chance that the IRR will be negative. 
Figure 6. Probability Distributions of Net Present Value from Monte Carlo Simulations ${ }^{\mathrm{a}}$

\section{Ten-year horizon}

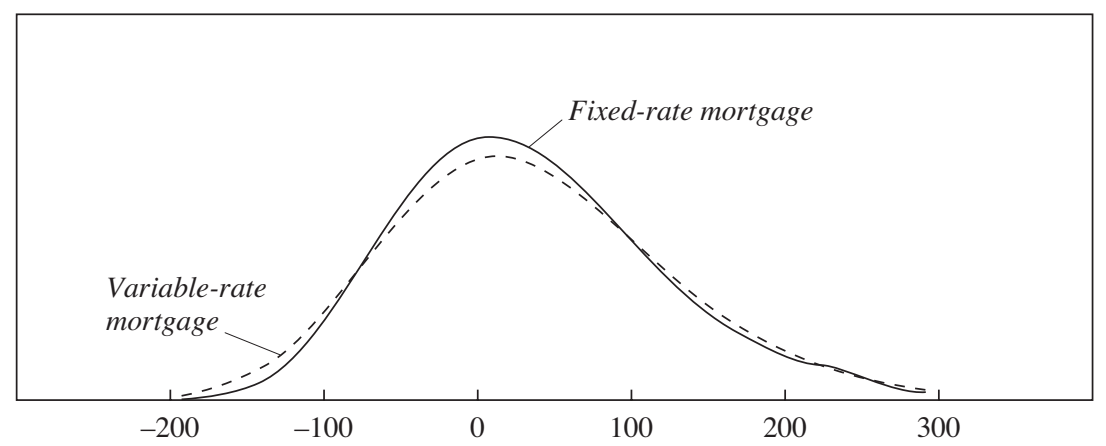

Infinite horizon

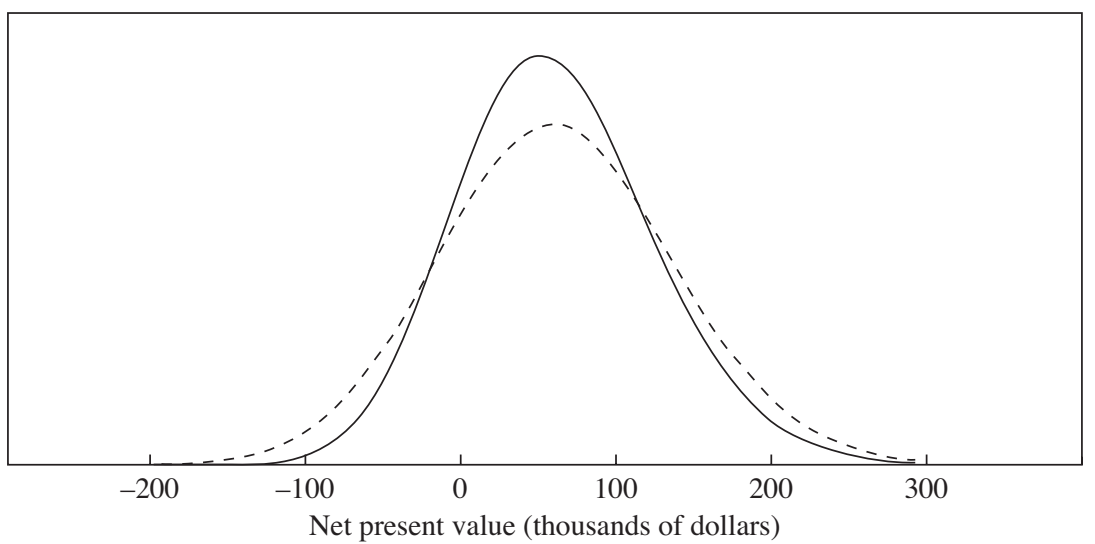

Source: U.S. Census Bureau, OFHEO house price indexes, BLS owner's equivalent rent indexes, and authors' calculations using data from various multiple listing services.

a. Calculated for a single matched pair of houses in Southern California (see appendix).

Together table 10 and figure 6 show that, first, the probability distribution for a variable-rate mortgage is somewhat more dispersed than that for a fixed-rate mortgage, because of the increased cash flow risk; and second, the probability distribution for a ten-year horizon is more dispersed than for an infinite horizon, because of uncertainty regarding the sale price. 
Table 11. Median Fundamental Values for Different Mortgage Rates, Required Rates of Return, and Time Horizons

Dollars

\begin{tabular}{|c|c|c|c|c|c|c|}
\hline \multirow[b]{3}{*}{ Market } & \multicolumn{6}{|c|}{ Median fundamental value of home when } \\
\hline & \multicolumn{2}{|c|}{$\begin{array}{l}\text { Annual mortgage } \\
\text { rate }=4.7 \% \text {, } \\
\text { required rate of } \\
\text { return }=5.3 \% \text {, and } \\
\text { horizon is }\end{array}$} & \multicolumn{2}{|c|}{$\begin{array}{l}\text { Annual mortgage } \\
\text { rate }=5.7 \%, \\
\text { required rate of } \\
\text { return }=6.0 \% \text {, and } \\
\text { horizon is }\end{array}$} & \multicolumn{2}{|c|}{$\begin{array}{l}\text { Annual mortgage } \\
\text { rate }=\text { required rate } \\
\text { of return }=6.7 \%, \\
\text { and horizon is }\end{array}$} \\
\hline & Ten years & Infinite & Ten years & Infinite & Ten years & Infinite \\
\hline $\begin{array}{c}\text { San Mateo } \\
\text { County }\end{array}$ & 926,311 & 831,616 & 715,600 & 661,475 & 578,677 & 549,115 \\
\hline $\begin{array}{l}\text { Orange } \\
\text { County }\end{array}$ & 968,541 & 888,224 & 755,551 & 711,891 & 621,740 & 595,126 \\
\hline $\begin{array}{l}\text { Los Angeles } \\
\text { County }\end{array}$ & 876,989 & 790,470 & 675,709 & 630,800 & 549,236 & 523,939 \\
\hline Boston & 776,790 & 712,529 & 591,930 & 565,315 & 478,040 & 467,820 \\
\hline Chicago & 655,848 & 580,994 & 505,874 & 470,725 & 411,380 & 394,627 \\
\hline $\begin{array}{l}\text { San Bernardino } \\
\text { County }\end{array}$ & 812,875 & 729,944 & 627,472 & 582,309 & 510,593 & 484,191 \\
\hline Dallas & 312,339 & 289,430 & 260,088 & 248,019 & 222,994 & 216,607 \\
\hline New Orleans & 452,159 & 408,740 & 353,051 & 333,353 & 289,326 & 280,956 \\
\hline Atlanta & 433,065 & 387,807 & 349,732 & 325,730 & 293,305 & 280,191 \\
\hline Indianapolis & 538,412 & 470,175 & 402,541 & 372,609 & 314,061 & 305,924 \\
\hline
\end{tabular}

Source: Authors' calculations using data from various multiple listing services.

\section{Predicting Policy Effects}

Our model can also be used to predict the effects of various policy actions on fundamental values. For example, if our general conclusionthat there may be some frothy local markets, but there is no national bubble in single-family home prices-is correct, then monetary policy is a blunt instrument for letting the air out of local bubblets. Should the Federal Reserve increase interest rates and lower fundamental values in Atlanta, Dallas, and Indianapolis in order to deflate San Mateo? Table 9 showed the predicted effects on housing premiums of changes in mortgage rates and required returns, due perhaps to changes in inflation or monetary policy. Another way to look at these data is by examining the predicted changes in fundamental values shown in table 11. Changes in mortgage rates and required rates of return clearly have substantial effects on fundamental values. 
Table 12. Median Fundamental Values under Different Tax Treatments of Home Mortgage Interest

Dollars

\begin{tabular}{|c|c|c|c|c|c|c|}
\hline \multirow[b]{3}{*}{ Market } & \multicolumn{6}{|c|}{ Median fundamental value of home when mortgage interest } \\
\hline & \multicolumn{2}{|c|}{$\begin{array}{l}\text { Is deductible as } \\
\text { under current law } \\
\text { and horizon is }\end{array}$} & \multicolumn{2}{|c|}{$\begin{array}{l}\text { Qualifies for a } \\
15 \% \text { tax credit } \\
\text { and horizon is }\end{array}$} & \multicolumn{2}{|c|}{$\begin{array}{l}\text { Receives no tax } \\
\text { benefit and } \\
\text { horizon is }\end{array}$} \\
\hline & Ten years & Infinite & Ten years & Infinite & Ten years & Infinite \\
\hline $\begin{array}{c}\text { San Mateo } \\
\text { County }\end{array}$ & 715,600 & 661,475 & 606,172 & 620,813 & 515,864 & 579,376 \\
\hline $\begin{array}{l}\text { Orange } \\
\text { County }\end{array}$ & 755,551 & 711,891 & 650,016 & 670,071 & 558,648 & 627,988 \\
\hline $\begin{array}{l}\text { Los Angeles } \\
\text { County }\end{array}$ & 675,709 & 630,800 & 575,050 & 591,519 & 490,436 & 552,905 \\
\hline Boston & 591,930 & 565,315 & 506,110 & 530,983 & 434,074 & 496,402 \\
\hline Chicago & 505,874 & 470,725 & 434,816 & 443,831 & 374,413 & 416,423 \\
\hline $\begin{array}{l}\text { San Bernardino } \\
\text { County }\end{array}$ & 627,472 & 582,309 & 534,138 & 546,831 & 456,263 & 510,503 \\
\hline Dallas & 260,088 & 248,019 & 232,696 & 237,355 & 207,017 & 225,944 \\
\hline New Orleans & 353,051 & 333,353 & 311,246 & 317,326 & 274,087 & 300,421 \\
\hline Atlanta & 349,732 & 325,730 & 307,673 & 309,731 & 269,918 & 293,245 \\
\hline Indianapolis & 402,541 & 372,609 & 336,039 & 349,052 & 280,465 & 325,223 \\
\hline
\end{tabular}

In November 2005 the President's Advisory Panel on Federal Tax Reform proposed changing the tax treatment of mortgage interest, noting that many countries, including Australia, Canada, and the United Kingdom, do not allow a home mortgage interest deduction in calculating taxable income as the United States does. ${ }^{27}$ To make their proposal somewhat more politically palatable, the panel recommended replacing the federal mortgage interest deduction with a tax credit equal to 15 percent of the mortgage interest paid that year, subject to some maximum. Because the details of this proposal are unclear, we analyze the effects on fundamental values of two policies: complete elimination of the interest deduction, and its replacement with a 15 percent tax credit without a cap.

Table 12 shows the implied median fundamental values for each market for a ten-year horizon and an infinite horizon. Relative to the current deductibility of mortgage interest, the 15 percent credit would reduce our

27. President's Advisory Panel on Federal Tax Reform (2005). 
median estimates of fundamental value across cities by 11 to 17 percent for a ten-year horizon and by 4 to 6 percent for an infinite horizon, and the elimination of the tax benefit would reduce our median estimates of fundamental values by 20 to 30 percent for a ten-year horizon and by 9 to 13 percent for an infinite horizon. Looked at the other way around, and using a ten-year horizon, the current deductibility of mortgage interest increases our median estimates of fundamental values across cities by 12 to 20 percent relative to a 15 percent tax credit (assuming a 28 percent marginal federal income tax rate) and by 26 to 44 percent relative to the absence of tax benefits.

\section{So Why Have Housing Prices Increased?}

If our conclusion - that homes in the urban housing markets we studied are not wildly out of line with fundamentals-is correct, how do we explain the recent run-up in housing prices? There are two possible explanations: fundamentals have increased rapidly, or prices were substantially below fundamental values in the past and this discount has been shrinking as prices have moved closer to fundamental values. We cannot say how much of the increase in housing prices is due to each factor without expanding our present study to include historical estimates of the valuation premium in each of these ten markets.

That task is far beyond the scope of this paper. But our anecdotal evidence is that, at least in that part of Los Angeles County where we live, home prices three to five years ago were much further below fundamental values than they are today. One of the authors of this paper is not only an economics professor but also a certified financial planner and has been advising prospective homebuyers for several years. Until very recently it was clear that buying a home was more financially advantageous than renting one; the decision now is much less obvious.

For a modest test of this anecdotal evidence, we collected matched rental and sale data for Los Angeles County for 2001 through 2004, to supplement our 2005 data. This is a particularly interesting time period, since the OFHEO index of housing prices for the Los Angeles metropolitan area doubled during these five years. We followed exactly the same procedure used for our 2005 study. We were able to obtain between 84 and 121 matched pairs for each year and, as before, adjusted all rents and sale 
Table 13. Median Internal Rates of Return and Premiums for Matches in Los Angeles County

Percent

\begin{tabular}{ccccccc}
\hline & & \multicolumn{2}{c}{ Median after-tax IRR } & & \multicolumn{2}{c}{ Median premium $^{\mathrm{a}}$} \\
Year & $\begin{array}{c}\text { No. of } \\
\text { observations }\end{array}$ & $\begin{array}{c}\text { Ten-year } \\
\text { horizon }\end{array}$ & $\begin{array}{c}\text { Infinite } \\
\text { horizon }\end{array}$ & & $\begin{array}{c}\text { Ten-year } \\
\text { horizon }\end{array}$ & $\begin{array}{c}\text { Infinite } \\
\text { horizon }\end{array}$ \\
\hline 2001 & 84 & 15.06 & 12.28 & & -40 & -36 \\
2002 & 97 & 14.18 & 11.29 & & -42 & -37 \\
2003 & 121 & 12.29 & 9.49 & & -42 & -37 \\
2004 & 89 & 8.59 & 7.17 & & -19 & -14 \\
2005 & 103 & 7.86 & 6.62 & & -17 & -11 \\
\hline
\end{tabular}

Source: Authors' calculations using data from multiple listing service for Los Angeles.

a. Percentage by which the market price exceeds fundamental value.

prices to July 15 of each year. After determining historical values for the model's parameters (mortgage rates, tax rates, homeowner's insurance, and so on), we calculated the after-tax IRRs and valuation premiums for each matched pair. The resulting median values for each year are shown in table 13. Consistent with our anecdotal evidence, home prices were substantially below fundamental values three to five years ago. After 2003 the after-tax IRR dropped sharply, and the discount of prices to fundamental values narrowed dramatically.

We do not have matched-pair data for earlier years, but perhaps we can assume that historical movements in matched-pair sale prices and rents are reasonably well approximated by the OFHEO housing price index and the BLS owner's equivalent rent index. In our 2001 matched-pair data the average sale price was $\$ 320,714$, and the average ratio of monthly rent to sale price was 0.00598 , implying a monthly rent of $0.00598(\$ 320,714)=$ $\$ 1,920$. We used the Los Angeles OFHEO housing price index and BLS rent index to extrapolate the $\$ 320,714$ home price and $\$ 1,920$ forward to 2005 and backward to 1983 (the earliest year for which both OFHEO and BLS data are available). This yielded an annual set of hypothetical matched rents and sale prices. For simplicity, we assumed 3 percent anticipated annual growth in rents throughout this period-surely a conservative estimate in the early 1980s. Historical values for mortgage rates, tax rates, and the model's other parameters were then used to estimate aftertax IRRs and valuation premiums for each year from 1983 through 2005.

Figure 7 shows these price and value estimates for an infinite horizon. In 1983 and 1984, even with an interest rate on thirty-year mortgages of 
Figure 7. Los Angeles County: Mean Actual Price and Calculated Fundamental Value, 1983-2005

Thousands of dollars

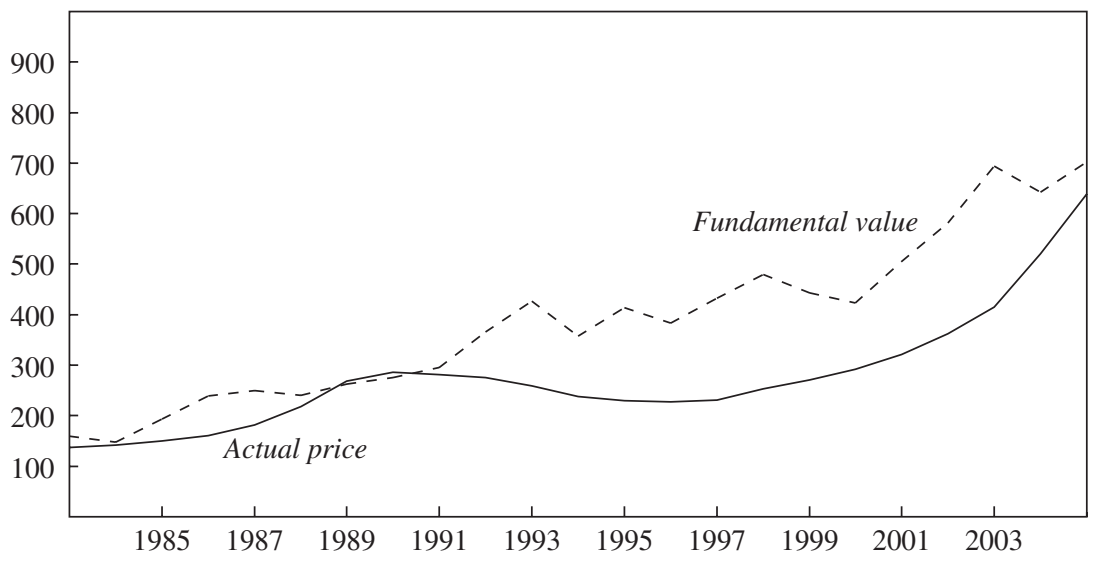

Source: U.S. Census Bureau, OFHEO house price indexes, BLS owner's equivalent rent indexes, and authors' calculations using data from various multiple listing services.

a. Values are for July of the indicated year.

roughly 13 percent and assuming only a 3 percent annual increase in rents, sale prices were 14 percent below fundamental values. In 1984 the thirtyyear mortgage rate rose to 14.7 percent, and fundamental values dipped, reducing the valuation discount from 14 percent to 4 percent. Then mortgage rates started falling, and fundamental values temporarily raced ahead of market prices. Between 1985 and 1990, market prices nearly doubled and the discount disappeared. Mortgage rates kept falling - from 10.1 percent in 1990 to 6.9 percent in 1998 - but home prices declined, opening up a huge gap between fundamental values and market prices. After 1996, market prices began rising again but mortgage rates kept falling-from 8.1 percent in 2000 to 5.8 percent in 2003 - and market prices were still well below fundamental values. For the eleven-year period 1993-2003, our analysis would have clearly favored buying over renting for households with long horizons. Mortgage rates stabilized in 2004 and 2005, and rapidly rising market prices reduced the discount to less than 10 percent.

Figure 8 shows the estimated valuation premiums: the percentage by which the market price was above or below fundamental value. The similar movements of the premium estimates based on the matched-pair data 
Figure 8. Los Angeles County: Premium of Actual Price over Fundamental Value, 1983-2005

Percent

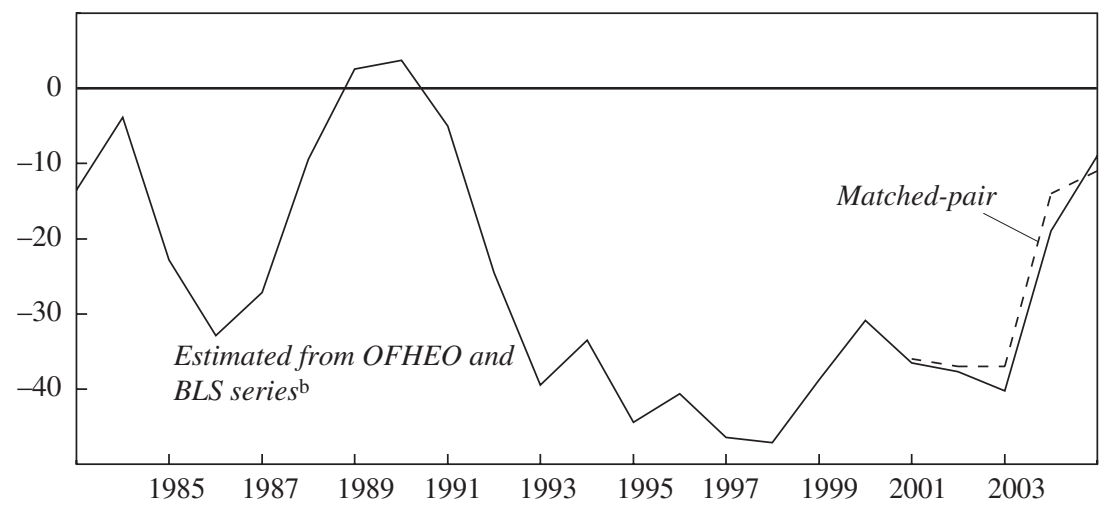

Source: U.S. Census Bureau, OFHEO house price indexes, BLS owner's equivalent rent indexes, and authors' calculations using data from various multiple listing services.

a. The premium is the percentage by which the market price exceeds the fundamental value. Fundamental value is calculated using rent projections for an infinite horizon. Values are for July of the indicated year.

b. Extrapolated from OFHEO house price indexes and the BLS owner's equivalent rent index.

and the extrapolated data during the years 2001-05 are reassuring. It is striking that the premium was negative (with prices below fundamental value, and often far below) for twenty-one of these twenty-three years. So why did housing prices in Los Angeles County double between 2001 and 2005? By our reckoning, fundamental values increased by about 40 percent during this period, and the discount of prices from fundamental values, which had been nearly 40 percent in 2001, shrank to less than 10 percent in 2005.

These calculations reveal a fundamental problem with regression models of housing prices that assume that market prices have historically fluctuated around fundamental values, being above fundamental values about as often as below. Such models assume that because current Los Angeles market prices are well above the values predicted by these regression models, they must also be well above fundamental values. If, in fact, the historical market prices used to estimate these models have consistently been well below fundamental values, then current market prices need not be above fundamental values.

Figure 9 shows similar backcast calculations for the nine other markets. In each case we use the OFHEO and BLS indexes and median 
Figure 9. Mean Actual Prices and Calculated Fundamental Values, 1983-2005 ${ }^{\text {a }}$

San Mateo County

Thousands of dollars

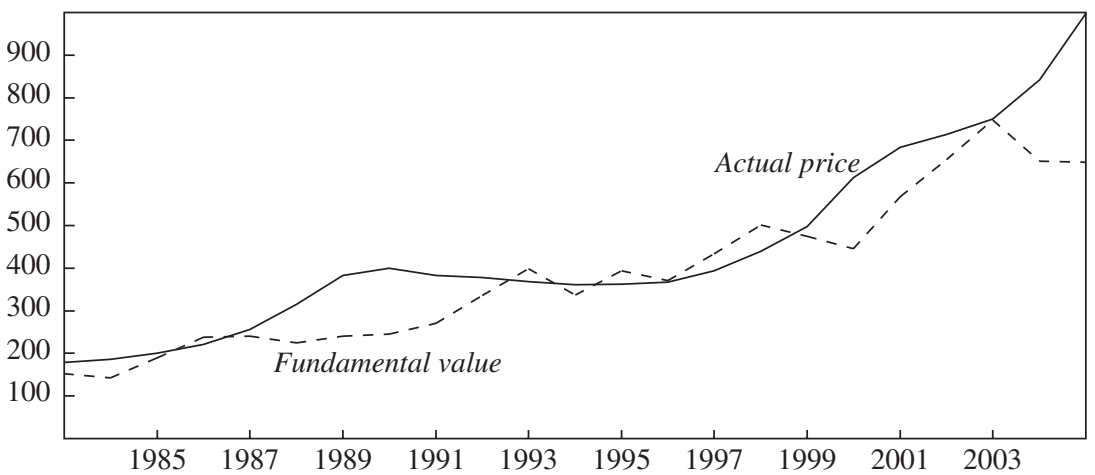

Thousands of dollars

Orange County

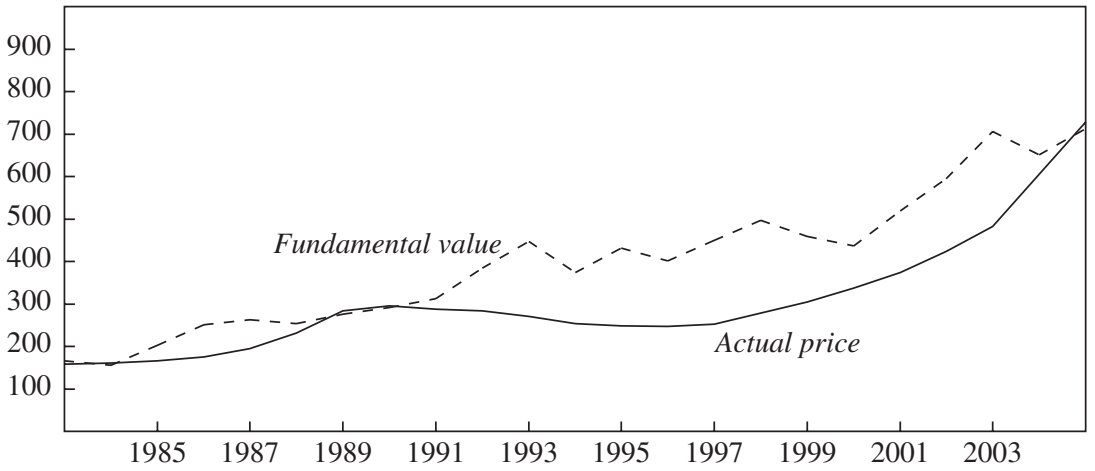

Thousands of dollars

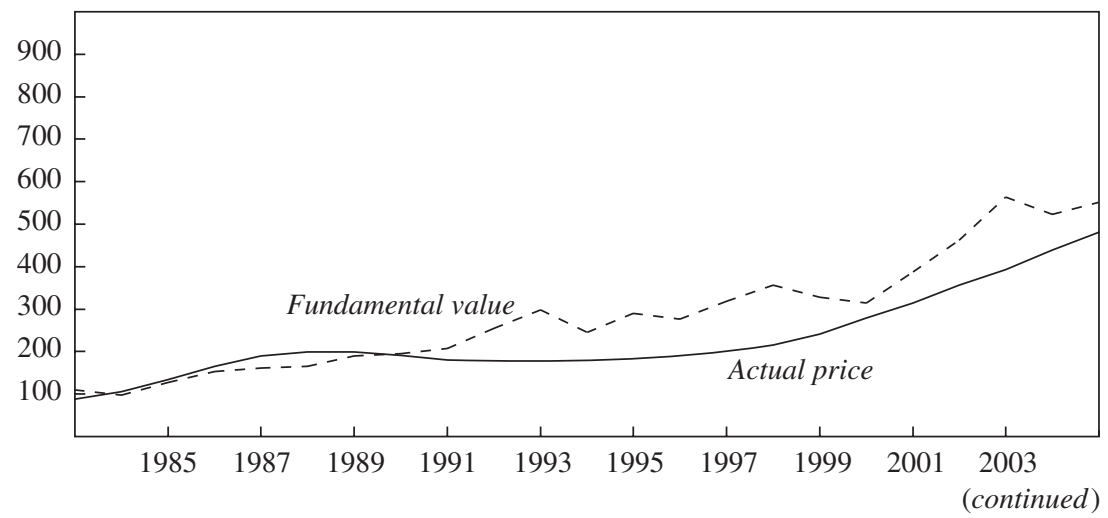


Figure 9. Mean Actual Prices and Calculated Fundamental Values, 1983-2005 ${ }^{\mathrm{a}}$ (continued)

Thousands of dollars

\section{Chicago}

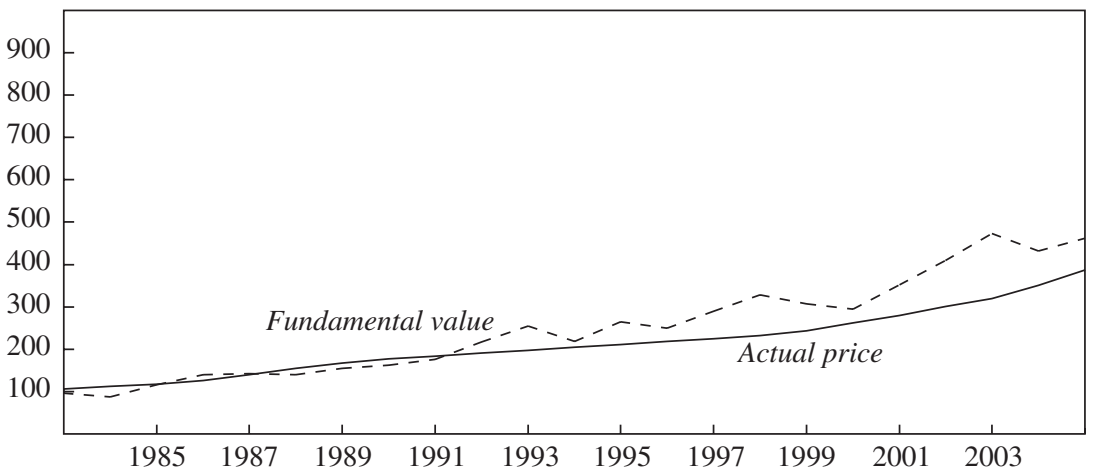

Thousands of dollars

San Bernardino County

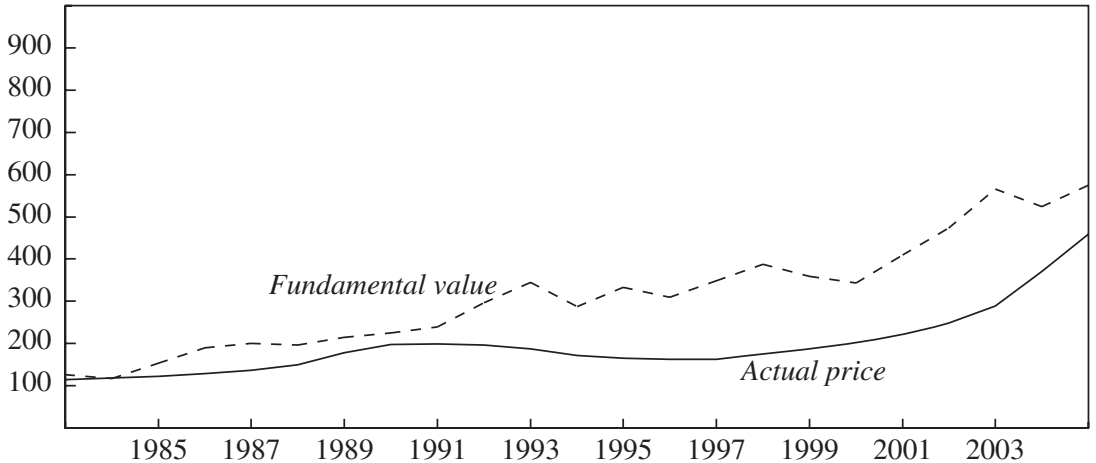

Dallas

Thousands of dollars

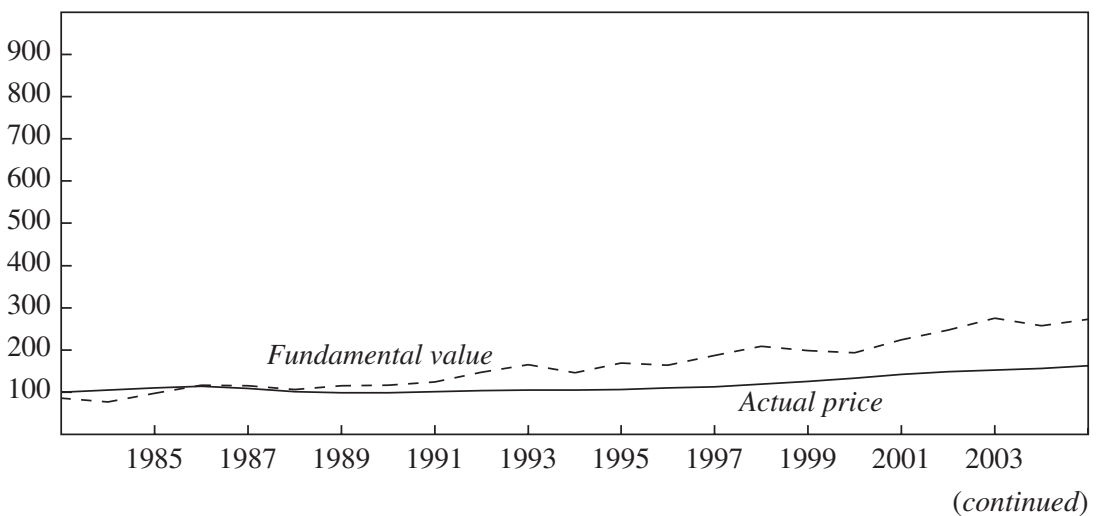


Figure 9. Mean Actual Prices and Calculated Fundamental Values, 1983-2005 ${ }^{\mathrm{a}}$ (continued)

Thousands of dollars

\section{New Orleans}

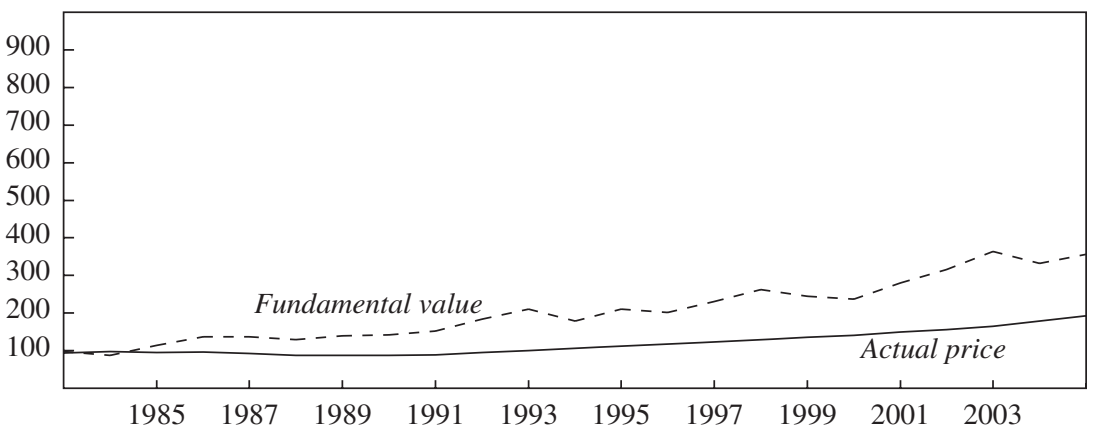

Atlanta

Thousands of dollars

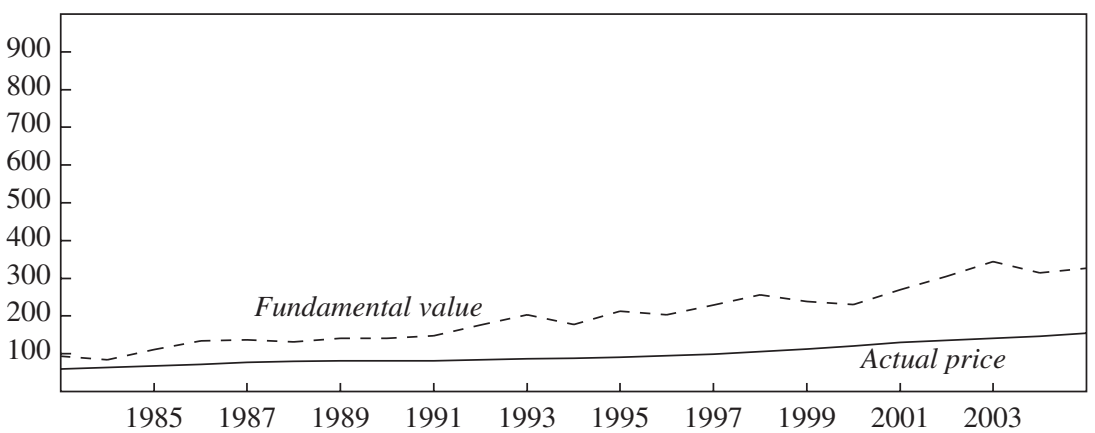

Thousands of dollars

\section{Indianapolis}

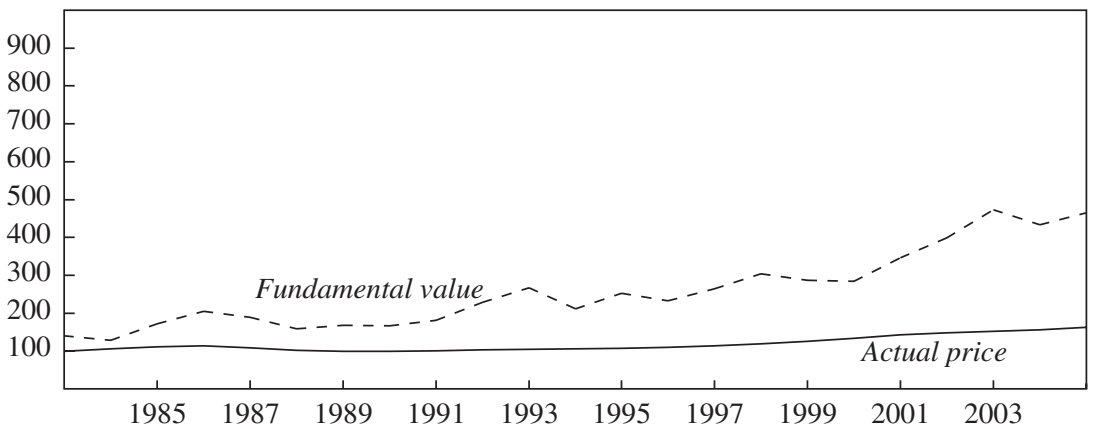

Source: U.S. Census Bureau, OFHEO house price indexes, BLS owner's equivalent rent indexes, and authors' calculations using data from various multiple listing services.

a. Values are for July of the indicated year. 
matched-pair data for 2005 to estimate hypothetical matched sale prices and rents for each year back to 1983. As in the Los Angeles County case, historical parameter values were then used to estimate after-tax IRRs and fundamental values for each year.

At any point in time, fundamental values differ across housing markets primarily because of differences in rents and in state tax laws; the zigs and zags in fundamental values over time are fairly similar because they are mostly caused by changes in interest rates, changes in federal tax laws, and other macroeconomic events. However, the changes in market prices over time are quite different across markets. San Mateo prices are quite volatile and were above fundamental value more often than below. San Bernardino and Orange County were much like neighboring Los Angeles County: prices were generally below fundamental values, with a run-up to close to fundamental values in the late 1980s, then a falling off, followed by an eventual closing of the gap by 2005. In Boston, Chicago, and Dallas prices were close to fundamentals for much of the 1980s but have lagged behind since then. In New Orleans market prices were briefly close to fundamentals in 1983 and 1984 but have since been below fundamentals. In Atlanta and Indianapolis market prices have remained well below fundamental values for twenty-three years.

If one were to use different macroeconomic assumptions-for example, a substantially higher or lower required return - the fundamental values in all ten areas would be adjusted in the same direction. Thus, if the required return were increased sufficiently to get fundamental values aligned with market prices in Indianapolis and Atlanta, fundamental values would be far below market prices in many of the other cities. These data reinforce our earlier argument that market prices do not appear to fluctuate randomly about fundamental values.

\section{Findings from a Mail Survey}

We also conducted a small mail survey to gauge how home purchases might be influenced by financial considerations. Surveys were mailed to 1,000 randomly selected households (100 in each of our ten housing markets) who had purchased homes in July 2005. The key question was, "If you hadn't bought this house, but were renting it instead, how much would you be willing to pay for rent each month?" From our sales data we already 
Table 14. Mean Physical Characteristics of Observed and Surveyed Homes

\begin{tabular}{|c|c|c|c|c|c|c|c|c|}
\hline \multirow[b]{2}{*}{ Market } & \multicolumn{4}{|c|}{ Observed perfect matches } & \multicolumn{4}{|c|}{ Homes of survey respondents } \\
\hline & $\begin{array}{l}\text { No. of } \\
\text { obs. }\end{array}$ & Bedrooms & Baths & $\begin{array}{l}\text { Square } \\
\text { feet }\end{array}$ & $\begin{array}{l}\text { No. of } \\
\text { obs. }\end{array}$ & Bedrooms & Baths & $\begin{array}{l}\text { Square } \\
\text { feet }\end{array}$ \\
\hline $\begin{array}{l}\text { San Mateo } \\
\text { County }\end{array}$ & 4 & 3.00 & 2.00 & 1,775 & 12 & 3.33 & 2.12 & 1,802 \\
\hline $\begin{array}{l}\text { Orange } \\
\text { County }\end{array}$ & 10 & 3.90 & 2.60 & 2,166 & 11 & 3.55 & 2.57 & 2,034 \\
\hline $\begin{array}{l}\text { Los Angeles } \\
\text { County }\end{array}$ & 10 & 3.50 & 2.17 & 1,790 & 7 & 3.71 & 2.25 & 1,858 \\
\hline Boston & 3 & 3.33 & 2.67 & 2,352 & 8 & 3.25 & 1.94 & 1,756 \\
\hline Chicago & 1 & 3.00 & 4.00 & 4,934 & 5 & 3.60 & 1.66 & 2,021 \\
\hline \multicolumn{9}{|c|}{ San Bernardino } \\
\hline County & 27 & 3.59 & 2.37 & 1,824 & 10 & 3.70 & 2.45 & 1,934 \\
\hline Dallas & 7 & 3.00 & 1.79 & 1,447 & 15 & 2.80 & 1.89 & 1,655 \\
\hline New Orleans & 1 & 4.00 & 3.00 & 2,900 & 8 & 3.00 & 2.00 & 1,892 \\
\hline Atlanta & 24 & 3.71 & 2.58 & n.a & 9 & 3.22 & 2.06 & n.a. \\
\hline Indianapolis & 15 & 3.07 & 2.13 & 1,659 & 9 & 3.33 & 2.33 & 1,924 \\
\hline
\end{tabular}

Source: Authors' calculations using data from various multiple listing services and the survey described in the text.

knew the sale price and the number of bedrooms and baths and the average square footage of these houses. Our survey was intended to gauge preferences by putting a dollar figure on how much the buyers valued living in their house, or what we will call its "rental value." Responses were received from 94 out of the 1,000 households.

One potentially appealing feature of these data is that each response yields sale price and rent data for a single house. If the respondents' rental estimates are reliable, then surveys such as this one might be a feasible way of gathering data for gauging the fundamental value of homes in different housing markets. To assess the reliability of the survey responses, we compared the implied fundamental values with those derived from the perfect matches we observed.

Table 14 shows the average number of bedrooms and bathrooms and the average square footage of the observed homes analyzed above and of the surveyed homes. The samples seem generally comparable with respect to these three characteristics, the exceptions being the very small samples for Boston, Chicago, and New Orleans. Table 15 shows several financial characteristics of the same two sets of properties (the results for Boston, Chicago, and New Orleans should not be taken too seriously). It is particularly striking that the sale prices were usually higher for the survey homes 
Table 15. Financial Characteristics of Observed Perfect Matches and Surveyed Homes

\begin{tabular}{|c|c|c|c|c|c|c|c|c|}
\hline \multirow[b]{2}{*}{ Market } & \multicolumn{4}{|c|}{ Observed perfect matches } & \multicolumn{4}{|c|}{ Homes of survey respondents } \\
\hline & $\begin{array}{c}\text { No. } \\
\text { of } \\
\text { obs. }\end{array}$ & $\begin{array}{c}\text { Mean } \\
\text { sale } \\
\text { price } \\
\text { (dollars) }\end{array}$ & $\begin{array}{c}\text { Mean } \\
\text { monthly } \\
\text { rent } \\
\text { (dollars) }\end{array}$ & $\begin{array}{c}\text { Median } \\
\text { premium }^{\mathrm{a}} \\
\text { (percent) }^{\text {pere }}\end{array}$ & $\begin{array}{c}\text { No. } \\
\text { of } \\
\text { obs. }\end{array}$ & $\begin{array}{c}\text { Mean } \\
\text { sale } \\
\text { price } \\
\text { (dollars) }\end{array}$ & $\begin{array}{c}\text { Mean } \\
\text { monthly } \\
\text { rent } \\
\text { (dollars) }\end{array}$ & $\begin{array}{c}\text { Median } \\
\text { premium } \\
\text { (percent) }\end{array}$ \\
\hline $\begin{array}{c}\text { San Mateo } \\
\text { County }\end{array}$ & 4 & $1,050,993$ & 2,858 & 40 & 12 & $1,109,883$ & 2,690 & 41 \\
\hline $\begin{array}{l}\text { Orange } \\
\text { County }\end{array}$ & 10 & 806,584 & 2,845 & -3 & 11 & 785,557 & 2,211 & 40 \\
\hline $\begin{array}{c}\text { Los Angeles } \\
\text { County }\end{array}$ & 10 & 544,225 & 2,194 & -22 & 7 & 627,526 & 1,985 & 34 \\
\hline Boston & 3 & 992,587 & 2,833 & -6 & 8 & 514,881 & 1,838 & -20 \\
\hline Chicago & 1 & 525,861 & 3,892 & -58 & 5 & 461,202 & 1,660 & -1 \\
\hline $\begin{array}{l}\text { San Bernardino } \\
\text { County }\end{array}$ & 27 & 459,227 & 1,971 & -26 & 10 & 473,783 & 1,746 & 2 \\
\hline Dallas & 7 & 141,204 & 1,241 & -53 & 15 & 246,970 & 1,020 & -2 \\
\hline New Orleans & 1 & 443,693 & 1,961 & -19 & 8 & 221,686 & 1,119 & -30 \\
\hline Atlanta & 24 & 204,884 & 1,508 & -53 & 9 & 291,081 & 1,333 & -10 \\
\hline Indianapolis & 15 & 97,744 & 1,034 & -75 & 9 & 187,114 & 767 & -37 \\
\hline
\end{tabular}

Source: Authors' calculations using data from various multiple listing services and the survey described in the text.

a. Percentage by which the market price exceeds fundamental value for an infinite horizon with no assumptions regarding price growth.

than for the observed homes, yet the estimated rental values were lower. These low rental values imply low fundamental values for these homes, in that the median premium was typically higher with the survey data than with the observed data.

Indianapolis is a strong example of this result, in that the average sale price for the surveyed homes is nearly twice the average sale price for the observed homes, yet the average estimated rental value is 25 percent lower. When one looks at the individual responses, it seems as if homebuyer-estimated rental values are quite different from actual rents. What are we to make of the household that purchased a four-bedroom, threebath, 2,430-square-foot home in Indianapolis for \$259,000 and estimated its rental value to be $\$ 650$ a month? For the Indianapolis homes in our sample with sale prices between $\$ 200,000$ and $\$ 300,000$, the average sale price was $\$ 236,000$ and the average monthly rent was $\$ 1,740$, with no home renting for less than $\$ 1,200$ a month. Eight of the nine survey responses from Indianapolis are below a least squares line relating rent to sale price for our observed Indianapolis data. 
We also asked those surveyed to predict the "annual rate of increase of this house's price over the next ten years." The median answer was 5 percent. For the forty-five respondents in Boston and the four California areas, the median answer was 7 percent; for the thirty-nine respondents in the other five markets, the median answer was 5 percent (Mann-WhitneyWilcoxon two-sided $\mathrm{p}=0.003$ ). These answers seem a bit optimistic, but certainly not delirious. ${ }^{28}$ It is also interesting that ten of our ninety-four respondents did not answer this question, instead putting a question mark, writing "not sure," or simply leaving it blank.

To be sure, there were some aggressive answers: sixteen of the eightyfour respondents (19 percent) who answered the question gave numbers larger than 10 percent, ranging all the way up to 50 percent for one cheerful or confused San Mateo household. (Did they really mean 50 percent a year for ten years, or 50 percent in total over ten years?) On the other hand, twenty-six ( 31 percent) gave answers below 5 percent. In Boston and the four California areas, eight respondents gave numbers below 5 percent, and thirteen above 10 percent. Overall, these homebuyers do not seem as out of touch with reality as were the stock buyers surveyed during the dotcom bubble, whose median expectation was 15 percent annual returns over the next ten years.

Overall, the homebuyers who responded to our survey seemed somewhat optimistic about future housing prices, which may be why they bought instead of rented. But they were inclined to give rental values substantially below market rents.

\section{Conclusion}

Measures of housing bubbles generally compare movements in home price indexes with the CPI, household income, rent indexes, or the values predicted by multiple regression models of housing prices. None of these measures can gauge whether housing prices are above or below fundamental values - the projected net rental savings, discounted by a required rate of return. Homebuyers do not seem to be a reliable source of information

28. Case and Shiller (2003) asked a similar question in a survey of persons who bought homes between March and August 2002 and received average answers of 13.1 percent in Orange County, 15.7 percent in San Francisco, 14.6 percent in Boston, and 11.7 percent in Milwaukee; we do not know why our survey obtained much lower numbers. 
about rental savings; instead, it seems safer to gather such data from market rents and sale prices of matched pairs of houses.

To gauge whether the projected cash flow from a home justifies the current price, with no assumptions about future prices, we look at an infinite horizon. In our data the median after-tax IRRs with an infinite horizon ranged from 4.6 percent in San Mateo to 21.2 percent in Indianapolis. With a ten-year horizon, and assuming that prices increase by 3 percent a year, the after-tax IRRs range from 3.5 percent in San Mateo to 23.6 percent in Indianapolis. For a homebuyer with a 6 percent after-tax required return, our baseline assumptions imply that the median San Mateo home sold for 54 percent above fundamental value with an infinite horizon and 42 percent above fundamental value with a ten-year horizon and home prices assumed to rise by 3 percent a year. In contrast, the median Indianapolis home sold for 65 percent below fundamental value with an infinite horizon and 68 percent below fundamental value with a ten-year horizon.

Housing prices in all of these areas can be justified by plausible, if perhaps somewhat optimistic, assumptions about the future growth of rent and sale prices. Even in San Mateo, the bubbliest city, homebuyers with a 6 percent after-tax required return would be better off buying than renting if rents and sale prices increase by 4 percent a year for the next ten years. In Atlanta, Dallas, New Orleans, and especially Indianapolis, residential real estate was cheap in the summer of 2005. Even with 2 percent annual rent growth and no growth in sales prices for ten years, the median Indianapolis homebuyer with a 6 percent after-tax required return bought a home for a price 37 percent below the house's fundamental value. All of these calculations underestimate the fundamental value of homes to the extent that homebuyers value privacy and other nonfinancial factors that we did not consider in our calculations. In addition, homebuyers who plan to live in a home for only ten years can usually reduce their mortgage rate by taking out a fifteen-year rather than a thirty-year mortgage.

In a bubble, market prices rise far above fundamental values calculated with reasonable assumptions about future cash flow. By this definition there was no bubble in the prices of single-family homes in 2005. It would take a very peculiar set of assumptions to place fundamental values in the middle of randomly fluctuating market prices for twenty-three years in all ten of the areas we examined. Thus historical market prices are an unreliable gauge of whether current market prices are above or below fundamental values. The observation that real estate prices are higher than 
they used to be or higher than the values predicted by models using historical prices does not prove that current prices are above fundamental values. The only way to answer that question is to estimate fundamental values.

Housing prices have increased rapidly in many urban markets in recent years, and some homebuyers have unrealistic expectations about future prices. The relevant question, however, is not how much prices have increased in the past or how fast people expect them to increase in the future, but whether, at current prices, a home is still a fundamentally sound investment. Our answer is generally yes, if the owner plans to stay in the area for many years to come.

\section{A P PENDIX}

\section{Monte Carlo Simulations}

Over 1983-2004 THE annual growth rates of Los Angeles-area rent and housing sale price indexes were 3.9 and 6.3 percent, respectively. We will work with monthly cash flows but assume that rent increases occur every twelve months. We simplify our simulations by assuming that price increases also occur at twelve-month intervals.

We use the following simple mean-reversion model to allow random variation in the growth of rent and sale prices around a long-run annual growth rate

$$
y-y_{-1}=\alpha\left(\ln [1+g]-y_{-1}\right)+\varepsilon,
$$

where $y$ is the natural log of the ratio of the current sale price (or rent) to the value a year earlier, $g$ is the long-run growth rate, $\alpha$ is the meanreversion coefficient, and $\varepsilon$ is a normally distributed error term. This model can also be written as

$$
y=\alpha\left\{\ln [1+g]+(1-\alpha) y_{-1}\right\}+\varepsilon .
$$

Least squares regressions using annual data for 1983-2005 yielded these estimates:

$$
\begin{aligned}
\text { rent: } y & =0.003+0.823 y_{-1}, t=6.66, \mathrm{SEE}=0.005, R^{2}=0.70 \\
\text { sale price: } y & =0.007+0.866 y_{-1}, t=6.19, \mathrm{SEE}=0.023, R^{2}=0.67 .
\end{aligned}
$$


The implied mean-reversion coefficients are 0.177 for rents and 0.134 for sale prices; the implied long-run annual growth rates are 1.59 percent for rents and 5.59 percent for sale prices. A least squares regression of the sale price residuals on the rent residuals gave a $t$ statistic of 1.21 and an $R^{2}$ of 0.07 , indicating that they are essentially uncorrelated.

One should not assume that the future will replicate the past, and, indeed, it is unlikely that sale prices for housing will continue to increase by 4 percentage points a year faster than rents. Our objective here is to see whether the purchase of a home can be justified financially with plausible assumptions about future increases in rents and sale prices. Our illustrative calculations assume 3 percent annual long-run growth rates and 0.2 mean-reversion coefficients for both rents and sale prices, a standard deviation of the rent error term of 0.005 , a standard deviation of the sale price error term of 0.020 , and zero correlation between the two error terms.

For modeling monthly changes in the Treasury rate, we use the discrete version of the well-known mean-reverting model of John Cox, Jonathan Ingersoll, and Stephen Ross: ${ }^{29}$

$$
R_{t}-R_{t-1}=\alpha\left(\beta-R_{t-1}\right)+\sigma \varepsilon \sqrt{R_{t-1}},
$$

where the long-run equilibrium interest rate is $\beta=0.057$, the meanreversion coefficient is $\alpha=0.20$, the instantaneous standard deviation is $\sigma=0.02$, and the stochastic term $\varepsilon$ is normally distributed with mean 0 and standard deviation 1.

The Federal Reserve has monthly interest data on one-year constantmaturity Treasury securities back to April 1954. Since we assume that the adjustments in the mortgage rate are based on the monthly-average interest rate at twelve-month intervals, we use the changes in monthly-average Treasury rates at that interval for guidance. During 1983-2004 the correlation between annual percentage-point changes in the one-year Treasury rate and Los Angeles-area housing sale prices was $0.11(\mathrm{p}=0.61)$, and the correlation between annual percentage-point changes in the one-year Treasury rate and Los Angeles-area rents was $-0.16(\mathrm{p}=0.47)$. One can also look at the historical correlations for more frequent data: quarterly for the sale price index and monthly for the rent index. The correlation between quarterly percentage-point changes in the one-year Treasury rate

29. Cox, Ingersoll, and Ross (1985). 
and Los Angeles-area sale prices was $0.12(\mathrm{p}=0.20)$, and the correlation between monthly percentage-point changes in the one-year Treasury rate and Los Angeles-area rents was $-0.01(\mathrm{p}=0.89)$. Our Monte Carlo simulations consequently assume that percentage changes in one-year Treasury rates are uncorrelated with rents and sale prices.

For $n$ independent simulations, each with a probability p of the NPV falling within a prespecified interval, the simulation standard error for the Monte Carlo estimate of $\mathrm{p}$ is approximately

$$
\sqrt{\frac{p(1-p)}{n}}
$$

One million simulations were used with a maximum standard error equal to 0.0005 . 


\section{Comments and Discussion}

Christopher Mayer: Before reading this paper by Margaret Hwang Smith and Gary Smith, I would have thought that almost any paper on which Robert Shiller and I were the discussants would have fallen somewhere between the two of us in its judgment on whether a housing bubble exists in the United States today. I recently wrote a paper with Charles Himmelberg and Todd Sinai that argues that there is not a housing bubble in most metropolitan markets, and that the cost of housing in most markets is close to its twenty-five-year average. ${ }^{1}$ Shiller, in contrast, has been outspoken about the possibility of a housing bubble. It turns out, however, that Shiller and I do not span the spectrum of views on this issue: the evidence in this paper suggests that housing in many parts of the country remains cheap. After the recent long and pronounced run-up in prices, I am surprised by this conclusion.

The question is one of both economic importance and social interest. Any article in any section of The New York Times or The Wall Street Journal that has the word "housing" in the title will likely be the top e-mailed article of the day. Even an op-ed on housing that I published in The Wall Street Journal turned out to be the top e-mailed article that day. Three years ago Karl Case and Shiller used a Lexis-Nexis search to demonstrate that the use of the words "housing bubble" and "housing boom" had reached record highs in major media publications. ${ }^{2}$ And things have become crazier since then.

1. Himmelberg, Mayer, and Sinai (2005).

2. Case and Shiller (2003). 
So how does one know if there's a housing bubble? In corporate finance, where data are much more readily available than for single-family houses, researchers determine whether the value of a firm is reflected in its stock price by comparing the latter to the net present value of projected earnings, dividends, or cash flow. Of course, economists argue over what is the right measure of cash flow and the right discount rate, how the risk premium varies over time, and so forth. But the basic concept of discounted net present value is widely accepted. Therefore what this paper is doing has to be right in some reasonably efficient real estate market. The problem is that many researchers have argued that real estate markets are far from efficient.

Application of the NPV relationship to housing has been hindered by the fact that it is difficult to observe rents for single-family homes. To compensate, researchers often use home price indexes, which, thanks to the pioneering research by Case and Shiller, ${ }^{3}$ have become much more easily available.

To begin, I think the paper could benefit from a more complete summary of the academic literature, to get a better perspective on this research. For example, James Poterba pioneered the user cost framework for valuing housing. ${ }^{4}$ This is the same framework that financial economists use to evaluate corporate investment, and it is closely related to an after-tax NPV analysis. Since then the user cost framework has been used in many analyses of housing, and it is not really so different from what the authors do here. Alternatively, Richard Meese and Nancy Wallace explicitly evaluated the present value relationship that the authors use here for a sample of homes in various communities in Northern California, although unlike the present authors they did not have a matched sample of rents and sale prices. ${ }^{5}$ Meese and Wallace concluded that home sale prices were above fundamental values in the late 1980s.

Other economists, such as Case and Shiller, ${ }^{6}$ look at imputed mortgage payment-to-income ratios and price-to-income ratios to get a rough idea of whether homes are overpriced. I would argue, however, that such measures are not great at measuring mispricing, because they do not reflect changes in interest rates, which surely ought to affect the value of any

3. Case and Shiller (1989).

4. Poterba (1984).

5. Meese and Wallace (1994).

6. Case and Shiller (2003). 
long-lived asset such as a home. Urban economists sometimes argue for an alternative measure that compares home prices with construction costs when the price of land is a relatively small percentage of total value.

For price index-based analyses, the difficulty in anchoring the equilibrium price to a reasonable baseline is a serious problem. In my recent article with Sinai and Himmelberg, ${ }^{7}$ we found that the real cost of housing in 2004 was about equal to its average over the last twenty-five years in most cities, and we concluded that there was no bubble in most of the country. But that benchmark was somewhat arbitrary. There is no way to know whether the average cost of housing over the last twenty-five years represents an equilibrium or is even the right benchmark.

Matched rent and price data do not help as much as might appear. The dollar-based data that the authors use in this paper would seemingly make it much easier to anchor the equilibrium price. Smith and Smith have gone to great effort to build an extremely comprehensive database of matched rents and prices - an admirable undertaking. Unfortunately, as I argue below, even with these wonderful data, appreciable problems remain.

The authors' baseline results (their table 6) indicate that homes in Atlanta and Indianapolis are underpriced by more than 50 percent, whereas homes in San Mateo County, California, are more than 50 percent overpriced. I am quite skeptical about these findings.

The paper reaches these findings by comparing the NPV of rent for a given home in their database with the recent sale price of a closely matched home. All of the paper's conclusions depend on many crucial assumptions, which I believe often bias the results toward buying rather than renting. For example, the analysis uses a 6 percent after-tax required rate of return even when the housing investment is highly leveraged by a typical mortgage. I think a more realistic required rate of return in those circumstances would be 8 or 9 percent. The analysis also assumes capital expenditure and maintenance costs that I believe are much too low, and the authors can only compare rents with prices at a single point in time. However, my most critical comment is that the analysis makes little effort to differentiate among cities whose past sale price and rent growth rates are quite different from each other.

7. Himmelberg, Mayer, and Sinai (2005). 
Superstar cities and expected appreciation and rent growth. I was particularly drawn to the analysis of houses in Indianapolis because my sisterand brother-in-law happen to live there. I know my relatives do not think that owning a house in Indianapolis yields a 21 percent internal rate of return. Maybe they just didn't know how to make the comparison of owning and renting that the authors do in this paper, but I think that other factors are at play as well.

My in-laws' comments about owning a house in Indianapolis are very insightful. Although neither my brother- nor my sister-in-law is an economist, they do understand supply and demand. They have repeatedly complained that every time home prices start to go up a little bit, home construction rises. Almost every major home builder operates in Indianapolis. Differences in the ability of developers to build new housing sharply separate Indianapolis from San Mateo. I doubt that homeowners in San Mateo are finding that builders are constructing a lot of houses around them. Not so coincidentally, past rates of home price appreciation are much higher in San Mateo than in Indianapolis, and future rates of appreciation will almost surely differ between these two markets. Yet the authors do not account for this point when comparing the investment potential of homes in these two cities.

From a corporate finance perspective, this would be like using priceearnings ratios to decide what stocks to buy without considering how expected future growth affects current valuation. No Wall Street analyst would try to determine whether stocks such as IBM, Google, and Amazon are overpriced or underpriced by assuming that these companies all expect the same average growth of earnings. Yet this paper, like many other studies of potential housing bubbles, treats homes in different cities as if they have the same expected rates of rent and sale price growth.

Rates of home price appreciation in these two cities have historically differed greatly, as is abundantly clear from the authors' table 2 . The fundamental question is how this historical pattern should affect expectations of future price appreciation. The authors do not address this issue.

If one looks at the data in the authors' table 6, the degree of over- or underpricing is clearly correlated with rates of past sale price appreciation. This would seem to beg the question: are people in San Mateo all just irrationally exuberant, whereas Chicagoans are somewhat exuberant, and people in Dallas are anchored by good old Southern values? Maybe they are, but I don't think so. 
When I taught executive education in San Francisco in 2001, I found my students there to be incredibly optimistic about how much their homes would appreciate in the future. (This was even after it was clear that the tech bubble was bursting.) Admittedly, these were MBA students, but I think they were fairly representative of attitudes about home prices in the Bay Area. When I go to Indianapolis, nobody-especially not my brother- and sister-in-law-seems to think their home is going to go up in value. My friends in Boston are somewhere in between: pretty optimistic, but not as optimistic as my San Franciscan MBA students. I suspect these differences are not just related to the current housing boom but also hold at other points in the economic cycle. ${ }^{8}$

Of course, it could be that these coastal markets are always more inclined toward bubbles, whereas homeowners elsewhere are less excitable. Yet homeowners along the coasts could be excused for being somewhat backward-looking in setting their expectations. After all, they can point to fifty years of data showing that home prices in these markets have consistently grown at above-average rates.

A recent working paper I co-wrote with Joseph Gyourko and Sinai uses Census data back to 1950 to demonstrate that long-run patterns of home price growth across markets are very persistent. ${ }^{9}$ Our data showed that real home prices in San Francisco appreciated at an annual average rate of 3.5 percent from 1950 to 2000, more than double the rate of home appreciation in the average metropolitan area over the same period. Homes in Boston, the New York area, and Seattle have also appreciated at aboveaverage rates. Yet real home prices in some Southern and Midwestern metropolitan areas have barely risen at all for the last fifty years. I should also note that the Census data in that paper do not include the exceptional growth rates of home prices from 2000 to 2005 . If our study had included the most recent data, the differences across metropolitan areas would have been even more pronounced. And zero is not a lower bound for the expected rate of price appreciation. My guess is that homes in, say, Ames, Iowa, have actually fallen in value after inflation, and real home prices in Houston today are lower than they were in 1975 . This is true in nearly every city in Texas, where new construction is easy and zoning laws are almost nonexistent.

8. Case and Shiller (1989).

9. Gyourko, Mayer, and Sinai (2006). 
Rates of home price appreciation in the Census data vary widely within decades because of cycles in individual markets, but the long-run changes are quite persistent. Half of the cities whose rate of home price growth was in the top quartile from 1940 to 1970 were also in the top quartile from 1970 to 2000, and many of the rest are just below that. This demonstrates that differences in appreciation across markets can be very persistent.

In what Gyourko, Sinai, and I call "superstar cities," we argue that these persistent differences in the rate of price growth across markets are related to two factors. First, cities differ (because of both regulation and geography) in the extent to which they allow new construction. Second, increases in population, combined with strong growth in the incomes of households in the upper tail of the distribution, have raised demand for the scarce opportunities to live in the superstar cities on the coasts. We show that home prices in cities like Boston, San Francisco, and New York are correlated with the number of wealthy families in the right tail of the national income distribution. Even more striking, prices of homes in the most expensive suburbs are tied to the right tail of the income distribution within their metropolitan areas.

This pattern could, of course, reverse itself tomorrow. But it certainly seems reasonable for homeowners to anticipate capital gains when they think about buying a home, and for those expectations to differ across markets. I think it is a serious omission to ignore expected future price (or rent) appreciation when considering whether households should rent or buy a home. Our Journal of Economic Perspectives article lays out how expected appreciation affects the user cost of housing and thus the warranted price of a home. ${ }^{10}$ But allowing for a greater rate of expected appreciation in San Mateo and Orange Counties and a much lower rate of appreciation in Indianapolis and Atlanta would greatly change the extent to which buying in the first two cities seems relatively expensive whereas buying in the second two appears to be a great bargain.

A six percent after-tax discount rate on equity is too low. The paper assumes a 5.7 percent annual mortgage rate but an after-tax equity rate of return of only 6 percent on a highly leveraged asset. As mentioned above, I think this required rate of return is too low.

A large tax benefit for owner-occupied housing cannot explain why the required rate of return is so low. Many homeowners do not itemize, and in

10. Himmelberg, Mayer, and Sinai (2005). 
the higher-priced cities, the alternative minimum tax further reduces that tax benefit from housing. I rent an apartment in New York City—not because I am pessimistic about the housing market but because Columbia University provides a really great deal on the apartment. But another disincentive to buying is that I almost fall subject to the alternative minimum tax because of New York city and state taxes alone. The same would be true if I rented in California. Of course, the biggest tax benefits of owner-occupied housing come from the nontaxability of imputed rents as income. Yet, by assuming high leverage, the paper minimizes this source of tax subsidy.

One way to set a benchmark for a reasonable required rate of return on equity would be to consider the cost of taking on additional leverage. Suppose a homeowner wanted to increase his or her leverage from 80 to 90 percent. The interest rate on a second mortgage for that additional borrowed money would likely be as high as 8 to 9 percent. As long as banks are correct about assessing the risk and return on this second mortgage-and this is a very competitive market - homeowners should not set their required rate of return any lower than a bank would. Of course, the last 10 percentage points of the capital structure, from 90 to 100 percent, poses even greater risk, and borrowers should expect to have to compensate for that added risk at an even higher rate. Thus a 6 percent required rate of return on equity is just too low when the cost of a first mortgage is 5.7 percent. Raising the required rate of return in this analysis would make housing look much more expensive than in the authors' calculations.

The assumed costs of owning are too low. The bias in the paper's other assumptions goes the same way. I think any owner of housing would say that 1 percent of home value for annual maintenance and capital expenditure is not enough. It may not seem low at first for those who mow their own lawn and shovel their own driveway. Yet a renter does not have to perform these tasks. Any apartment owner will tell you that 1 percent of the value of a property comes nowhere near their maintenance and capital costs of renting an apartment. I think 2 to 3 percent would be more realistic, if one includes both maintenance costs and capital requirement costs, and this range is what professional landlords use.

Other factors suggest that owning is better than renting. Although this paper makes the case for owning versus renting in most markets, it ignores a couple of important arguments that support that case. First, there is an appreciable moral hazard conflict between renters and owners. Tenants do not have the same incentive to properly care for a house as an 
owner does. And rental units are often vacant: according to Census data, between 5 and 10 percent of the time, on average. Tenants also can expect to have to move more frequently, unless they have a long-term contract. All of these considerations amount to a big spread between the rent a tenant pays and the return on investment an owner gets. Finally, as I mentioned above, there are large tax benefits from the nontaxability of owner-imputed rent: landlords must pay taxes on rental income, but owner-occupants face no such tax. Furthermore, under current tax law, the vast majority of capital gains are untaxed. After taking into account these rigidities between owning and renting, owning makes a lot of sense. The paper does not discuss these issues, although I think they are an important reason that owning is more attractive than renting for most households.

Finally, there are appreciable portfolio benefits from owning. Sinai and Nicholas Souleles show that owning a home is a very good way to hedge the risk that rents and sale prices will rise in the future. ${ }^{11}$ This is a huge benefit. Sinai and Souleles show that home prices reflect this benefit-that the price-to-rent ratio is higher, all else equal, in markets where the volatility of rents is higher. Any discussion of the benefits and costs of owning versus renting should consider these hedging benefits of owning a home.

In conclusion, the paper's underlying concept is sound, and the authors have made an admirable effort at collecting new and interesting data. But the implementation of the analysis has left out too many important factors, especially differences in expected appreciation across markets, that materially impact the conclusions. Their other assumptions also appear to make housing look cheap. Although I do not believe that housing is in a bubble in most markets, neither do I believe that housing is cheap, which is what the paper's analysis appears to show. With more realistic assumptions, I suspect that differences in pricing across cities would narrow appreciably, and housing would no longer look like a bargain in most of the country.

More generally, I am not optimistic that the authors' approach will solve some of the problems that have hampered previous analyses of home prices based on sale price and rent indexes. Even with their ambitious data collection effort, the authors do not have a long enough time series to accurately identify long-term growth rates for a matched sample of rents and prices on a given home. In addition, I still have questions about the representativeness of the data, given the relatively small sample size and the fact that

11. Sinai and Souleles (2005). 
relatively few single-family houses are rented. Thus any analysis of longrun housing changes must still rely on indexes to estimate growth rates, with all of the potential biases and changes in quality that implies. Although I believe a lot can be learned from studies based on price indexes, it will not be possible to improve the analysis further without a good time series of matched rent and price data. In addition, good accounting data on capital expenditure and maintenance are lacking for this matched sample of units.

Finally, I would urge strongly that future papers consider differences in expected price growth across cities, and not treat cities as basically the same. Home prices have behaved differently from city to city for sixty years and in all likelihood will do so in the future.

Robert J. Shiller: The question of whether investments in homes are attractive for individual investors-whether one should "own or rent"has been a perennial subject of popular discussion. But the question has taken on increased urgency in the past few years because of the enormous recent (and perhaps still ongoing) boom in home prices. I have argued elsewhere, using data back to 1890 , that this boom, which began in the late 1990s, is probably the biggest home price boom that the United States has ever seen. ${ }^{1}$

The question has taken on almost hysterical significance among some people, who seem to be reading and talking about real estate just about every day. Some renters are feeling a pang of regret that they did not invest in homes some years ago, when prices were, in many cases, half what they are today. But should they go into the market now after prices have risen so high that they raise the possibility of a bubble bursting? This public outpouring of interest and attention suggests that, ironically, the source of the price increases may be these very same expectations and worries of investors, which impel many of them to bid up home prices. That is the vicious circle that has driven speculative bubbles in the past, and the breaking of the circle has led to the bursting of such bubbles in the past.

Margaret Hwang Smith and Gary Smith do not actively question this characterization of investor attitudes, but they do not want to take it for granted that the emotions are the source of the boom or that there are any forces pushing prices to fall. They argue that the observed psychology could just be the consequence of the current boom, not its cause. It is certainly

1. Shiller (2006). 
conceivable that home prices could be close to fundamental values, if there is some reason why the psychological pressures are not as strong in promoting buying as they seem, or, alternatively, if the psychology was irrationally pessimistic in the past and prices were too low until now.

There is a great deal of empty talk and trading of stories in the news media, but little careful discussion of the issues. In contrast, this paper is a significant and timely contribution. I find it a rather idiosyncratic contribution, which focuses on some issues with great care and neglects others. Through the authors' analysis, the greatest speculative boom in home prices in the history of this country seems to vanish completely, and everything is rational and normal. One can profit a great deal from their analysis, but one must take it with a healthy dose of skepticism.

Why aren't construction professionals doing studies like this? The first question that comes to mind is what industry professionals think about investment returns in real estate. There are professional companies that invest in homes and rent them out. Why should a couple of college professors be able to judge the rental-sale price ratio better than the investment industry can?

But, strangely, there are very few professionals who invest in singlefamily homes. Why not? I spoke to Thomas Skinner, managing partner and founder of Redbrick Partners, which, although it bills itself as the biggest institutional investor in and manager of single-family homes in the United States, owns only about 1,000 homes. Skinner told me that about a third of all rentals in the United States are single-family homes, but that virtually all of these are managed by very small mom-and-pop operations. He told me, "It is operationally complex to put together an organization that owns and manages hundreds or thousands of geographically dispersed housing units." There is the difficulty of someone outside the community buying homes at a good price, given their incredible diversity of characteristics. There is also the problem of monitoring all the tenants, who not only might fail to maintain the homes but might actively destroy value.

There are many professional investors and rental managers of apartment buildings, who presumably know whether their rents are covering their costs. But their experience cannot help us understand the boom in singlefamily home prices, because the boom in apartment building prices seems largely to have fizzled out years ago. For example, according to the Global Real Analysis apartment price index for Boston, prices of apartment buildings there have been flat or falling in real terms since 2001. The housing 
boom is mostly a phenomenon of amateur investors, who do not have the resources to do careful studies.

Portfolio theory. There is another reason to listen to professors: the portfolio problem that homeowners face is deep and demands careful attention to financial theory. It requires quantifying life-cycle needs and opportunities, calculating covariance matrices of returns on investments in a variety of vehicles, including houses, as well as covariances of these returns with labor incomes, and solving an optimization problem with constraints imposed by the lumpiness of investments in homes and the costs of getting in or out of them. Moreover, in the case of single-family homes, financial theory would have to be adjusted to account for the obvious inefficiency of prices in these markets.

Financial theory generally considers investment decisions separately from consumption decisions, and the received doctrine would seem to imply that individuals should invest in a fully diversified portfolio (which, the capital asset pricing model would say, is a mixture of a market portfolio of risky assets from around the world and a riskless asset) and then, as an entirely separate decision, consume whatever one wants, including, by paying rent, the housing services of whichever house or apartment one desires. This theory would seem to reject strongly that people should invest in a home as a large part of the portfolio, because such a portfolio would be undiversified.

However, there are reasons consistent with financial theory to consider the consumption decision jointly with the investment decision. The tax law creates a link between the two decisions by specifying that implicit rent on owner-occupied homes is not taxed, thus providing an incentive to depart from full portfolio diversification by buying a home. Moreover, in the absence of complete long-term rental markets, there is a consumption-riskmanagement aspect to the decision. ${ }^{2}$ One might buy a home rather than rent, in order to insure against possible future changes in rents.

Smith and Smith do not attempt to adapt modern financial theory to these subtle problems but instead use an internal rate of return calculation. Rather than consider the home investment decision as part of a broader portfolio decision, they assume that the homeowner will buy if and only if the internal rate of return on the leveraged investment in the home exceeds 
a required rate of return, which they take, as a rule of thumb, to be equal to 6 percent.

Doing these IRR calculations does seem to be an improvement over the calculations that we see in newspaper accounts comparing owning with renting. The authors stress, justly, that these popular accounts tend to make the mistake of comparing the cost of renting today with the cost of owning today, without bearing in mind that rents may increase but fixed-rate mortgage payments will not. Their IRR calculations take care of that problem.

The IRR calculation may be an improvement over newspaper accounts, but it is still not ideal. The leverage assumption is critical in such calculations, because leverage generally will affect the IRR. The authors assume that the homeowner borrows 80 percent of the purchase price of the home. The 80 percent figure is derived not from financial theory but from what is actually just an old (and now outdated) convention that lenders used to impose on homebuyers. Calculating expected IRRs on leveraged investments and comparing these with a required rate of return that is not based on a formal model taking account of the leverage is just not in accordance with modern financial theory. That theory does not suggest that one can compute fundamental value by setting the IRR on a leveraged investment equal to an exogenous required rate of return. If one chose a different assumption about the down payment, thus changing the leverage, and held the assumed required return constant, one would get a different valuation.

Simulations. The authors estimate time-series models of rents and prices measured in nominal (not real) terms, using data for the past twenty years. They then say that, to be conservative, they will adjust these models to moderate the implied appreciation of home prices to just 3 percent a year (or 2 or 4 percent in other simulations). These are just guesses as to future appreciation in the housing market. The imposition of this narrow range of possible levels of appreciation compromises this paper and pushes its results in the direction of a statement of opinion rather than authoritative analysis.

Smith and Smith's confident assumption that rents will increase may be misplaced. Indeed, real rents (adjusted using the "rent of primary residence" component of the consumer price index) have actually declined about 0.7 percent a year over the ninety-two years between 1913 and 2005. Although this series suffers from some methodological shortcomings, ${ }^{3}$ it is plausible that real rents have indeed declined over the years because of

3. Hobijn (2002); Gordon and vanGoethem (2004). 
technological progress in home construction, and reflecting the wellestablished general decline in the real prices of manufactured goods. ${ }^{4}$

Even with the authors' possibly optimistic assumptions, the simulated results in their figure 6 show a lot of potential downside. With the ten-year horizon, even under their assumption of 3 percent expected rent and price growth, they find that for both fixed- and variable-rate mortgages, the probability of a negative net present value is 37.8 percent. Leveraged investments in housing can indeed turn out badly.

Biases in rent levels in the matched pairs data. I am concerned that the rent data that the authors took great pains to collect here may overstate the implicit rent that an owner-occupant can expect to receive. Note from their table 5 that there is a strong inverse correlation between the rent-sale price ratio and price. Why should this be? One likely factor is that there is a fixed cost to renting homes out (mainly basic maintenance and administrative costs), and this cost may be just as high for small homes as for big homes. Moreover, low-valued homes may tend to be in marginal neighborhoods, where vacancy rates or the risk of damage to the home may be higher.

These fixed costs of renting, on top of the tax disincentives to renting, tend to confine the rental market to people who plan to live in rented housing for only a short time. According to Skinner, the Redbrick executive, the average tenure in rented single-family homes is about 2.5 years. People who expect to move soon may be willing to pay a high rent to maintain their standard or habit of living, but might not be willing to do so in the long term.

I do not think, anyway, that owning versus renting is the only, or even the main, issue for most homeowners. Most Americans will end up eventually owning their primary residence because they want the stability, the ability to maintain and remodel to their tastes, and the sense of privacy that ownership provides. For most people a more important issue is how expensive a house to buy. It would be a mistake to conclude from the authors' IRRs that one should reach up to buy a very pricey house in Indianapolis, since one may not derive the same marginal utility of implicit rent that actual renters do, given their different circumstances. On the other hand, by the same reasoning, their conclusion that a house is "generally" a "fundamentally sound investment" is probably right, independent of their rent analysis: unless they expect a crash to happen soon, most people will want to buy a home of some size and get on with their lives.

4. Shiller (2006). 
Why have home prices gone up? The most provocative section of the paper is the one that tries to explain the recent boom in terms of fundamentals. Figure 7 compares an index of home prices in Los Angeles (one of the most spectacular boom cities) with a calculation of fundamental value. The two curves are hardly identical but do show similar uptrends. Does this clinch the case that most of the boom is rational?

Smith and Smith assume that the expected increase in home prices and rents stays fixed at 3 percent every year despite declining inflation expectations and declining nominal mortgage rates. This is enough to impart an upward trend to their calculated fundamental value of home prices since 1985 , since they are using a declining rate to discount a cash flow that grows at a constant rate. Thus they get an uptrend in nominal fundamental values that roughly matches the uptrend in nominal Los Angeles home prices. The same mechanism would apparently tend to predict dramatic uptrends in other cities, even cities that did not share the boom in Los Angeles, but these are not shown.

The supply side. The paper says nothing about the supply of housing. One venerable model of housing supply holds that home prices should track construction costs. If price rises above construction cost, builders will have an incentive to build, which will persist until price again falls to construction cost. If price falls below construction costs, builders cannot make a profit, and so supply will stagnate until population growth and the growth of the economy again raise price to construction cost. Looking at price relative to construction cost is conceptually easier than looking at price relative to rent, because the first ratio should revert toward a mean of 1.0 in equilibrium, whereas the second depends on difficult-to-measure and potentially time-varying real interest rates, risk premiums, and expectations about future real rents.

Land costs are not as important a factor in these construction costs as one might think. According to the U.S. Department of Agriculture, an acre of farm land in the United States still costs only about $\$ 2,000$, and one can usually get about seven lots out of an acre. There is plenty of cheap land, and new city centers are being built. Even in old established urban areas, new units can be built by tearing down low-rise buildings and putting up highrise buildings, and this can be seen happening on a massive scale in major U.S. cities by just looking at all the building cranes on city skylines today.

One can relate price to construction cost (up to an unknown scalar multiple) by taking the ratio of a home price index (I took our own Standard \& 
Poor's/Case-Shiller Home Price Index) for various cities to the price index for residential construction as defined in the National Income and Product Accounts. Some cities, such as Los Angeles and Boston, seem to show a slight uptrend in this ratio over the last several decades, and it is conceivable that this will continue, as Charles Himmelberg, Christopher Mayer, and Todd Sinai suggest in a recent paper. ${ }^{5}$ But the ratios for other cities remained extremely stable until the past five years. For example, in Miami the standard deviation of the natural log price-construction cost ratio was only 5.2 percent from 1972 to 2000, whereupon this log ratio suddenly shot up 68 percent (the actual price-construction cost ratio doubled). The suddenness of this departure of the ratio from its pre-2000 stability suggests that the situation today is anomalous, that the ratio is mean reverting, and that it will revert. (I saw a lot of building cranes in Miami on a trip there in early March 2006.)

Builders seem to be responding to this record-high price-construction cost ratio. Nationwide, residential fixed investment in 2005 was 6.1 percent of GDP, its highest level since 1950, when the country was trying to make up for a wartime ban on nondefense residential construction and to build housing for the returning soldiers and the new baby-boom families. In fact, 1950 is the only year since 1929 when residential investment as a share of GDP (and it was an isolated, sharp peak of 7 percent in 1950 alone) exceeded the 2005 value. This suggests that the biggest-ever boom in home prices is coming to an end soon, with possible price falls.

At present, MacroMarkets LLC, the company I co-founded with Allan Weiss and Samuel Masucci, is collaborating with the Chicago Mercantile Exchange (CME), Fiserv Inc., and Standard \& Poor's Corporation to create revolutionary new markets for futures and options on single-family homes for ten U.S. cities. The markets opened for trading at the CME on May 22, 2006, and although trading was slow at first, the open interest of the futures contracts exceeded $\$ 30$ million within about a month. These markets are generating forecasts for home prices out to a one-year horizon. Soon after they opened, the futures markets fell into backwardation (with higher prices for earlier than for later dates) for almost all cities, implying expected home price declines. Smith and Smith do not seem at all concerned about such price declines. We will find out soon enough whether the market forecasts are right when we see what actually happens to home prices.

5. Himmelberg, Mayer, and Sinai (2005). 


\section{References}

Anily, Shoshana, Jacob Hornik, and Miron Israeli. 1999. "Inferring the Distribution of Households' Duration of Residence from Data on Current Residence Time." Journal of Business and Economic Statistics 17(3): 373-81.

Baker, Dean. 2002. "The Run-Up in Home Prices: A Bubble." Challenge 45(6): 93-119.

Case, Karl E., and Robert J. Shiller. 1988. "The Behavior of Home Buyers in Boom and Post-Boom Markets." New England Economic Review (November/ December): 29-46. 1989. "The Efficiency of the Market for Single Family Homes." American Economic Review 79(1): 125-37.

. 2003. "Is There a Bubble in the Housing Market? An Analysis." BPEA, no. 2: 299-342.

Cox, John C., Jonathan E. Ingersoll, Jr., and Stephen A. Ross. 1985. "A Theory of the Term Structure of Interest Rates." Econometrica 53(2): 385-407.

DeKaser, Richard. 2005. "House Prices in America." Global Insight/National City Corporation.

Garber, Peter M. 2000. Famous First Bubbles: The Fundamentals of Early Manias. MIT Press.

Goodman, Allen C. 1988. "An Econometric Model of Housing Price, Permanent Income, Tenure Choice, and Housing Demand." Journal of Urban Economics 23: 327-53.

Gordon, Robert J., and Todd vanGoethem. 2003. "A Century of Housing Shelter Prices: How Big Is the CPI Bias?" Working paper. Northwestern University.

Gyourko, Joseph, Christopher Mayer, and Todd Sinai. 2006. "Superstar Cities." Working Paper 12355. Cambridge, Mass.: National Bureau of Economic Research (June).

Hansen, Kristin A. 1998. "Seasonality of Moves and Duration of Residence." U.S. Census Bureau Current Population Reports, Household Economic Studies P70-66 (October). Washington.

Himmelberg, Charles, Christopher Mayer, and Todd Sinai. 2005. "Assessing High House Prices: Bubbles, Fundamentals, and Misperceptions." Journal of Economic Perspectives 19(4): 67-92.

Hobijn, Bart. 2002. “On Both Sides of the Quality Bias in Price Indexes.” Staff Reports from the Federal Reserve Bank of New York 157 (December).

Kindleberger, Charles. 1987. "Bubbles." In The New Palgrave: A Dictionary of Economics, edited by John Eatwell, Murray Milgate, and Peter Newman. New York: Stockton Press.

Krainer, John, and Chishen Wei. 2004. "House Prices and Fundamental Value." FRBSF Economic Letter 2004-27. Federal Reserve Bank of San Francisco (October). 
Leamer, Edward E. 2002. "Bubble Trouble? Your Home Has a P/E Ratio Too." UCLA Anderson Forecast (June).

McCarthy, Jonathan, and Richard W. Peach. 2004. "Are Home Prices the Next 'Bubble'?" Federal Reserve Bank of New York Economic Policy Review 10(3): $1-17$.

Meese, Richard, and Nancy Wallace. 1994. "Testing the Present Value Relation for Housing Prices: Should I Leave My House in San Francisco?" Journal of Urban Economics 35(3): 245-66.

Peach, Richard W. 2005. "Is There a Housing Bubble?" Advance (TIAA-CREF), pp. 19-22 (Summer).

Poterba, James M. 1984. "Tax Subsidies to Owner-Occupied Housing: An AssetMarket Approach." Quarterly Journal of Economics 99(4): 729-52.

President's Advisory Panel on Federal Tax Reform. 2005. Simple, Fair and ProGrowth: Proposals to Fix America's Tax System. Report of the President's Advisory Panel on Federal Tax Reform. Washington (November). www. taxreformpanel.gov/final-report.

Rosen, Harvey S. 1979. "Housing Decisions and the U.S. Income Tax: An Econometric Analysis." Journal of Public Economics 11: 1-23.

Rosen, Harvey S., and Kenneth T. Rosen. 1980. "Federal Taxes and Home Ownership: Evidence from Time Series." Journal of Political Economy 88(1): $59-75$.

Shiller, Robert J. 2006. "Long-Term Perspectives on the Current Boom in Home Prices." Economists' Voice 3(4). www.bepress.com/ev/vol3/iss4/art4 (registration required).

Siegel, Jeremy J. 2003. "What Is an Asset Price Bubble? An Operational Definition." European Financial Management 9(1): 11-24.

Sinai, Todd, and Nicholas Souleles. 2003. "Owner-Occupied Housing as a Hedge against Rent Risk.” Working Paper 9462. Cambridge, Mass.: National Bureau of Economic Research (January).

2005. "Owner-Occupied Housing as a Hedge against Rent Risk." Quarterly Journal of Economics 120(2): 763-89.

Williams, John Burr. 1938. The Theory of Investment Value. Harvard University Press. 
